\title{
FISHES OF INLAND WATERS OF THE PHU QUOC ISLAND, GULF OF THAILAND, VIETNAM: ICHTHYOFAUNA STRUCTURE AND SOME REMARKS ON THE MAJOR EVOLUTIONARY TRENDS IN ITS GENESIS
}

\author{
Ekaterina D. VASIL'EVA ${ }^{1,2^{*}}$ and Victor P. VASIL'EV ${ }^{3,2}$ \\ ${ }^{1}$ Zoological Museum, Moscow State University, 125009 Moscow, Russia \\ ${ }^{2}$ Vietnam-Russian Tropical Center, Moscow, Russia and Ho Chi Minh, Vietnam \\ ${ }^{3}$ Severtsov Institute of Ecology and Evolution, Russian Academy of Sciences, 119071 Moscow, Russia
}

Vasil'eva E.D., Vasil'ev V.P. 2012. Fishes of inland waters of the Phu Quoc Island, Gulf of Thailand, Vietnam: ichthyofauna structure and some remarks on the major evolutionary trends in its genesis. Acta Ichthyol. Piscat. 42 (3): 193-214.

Background. The ichthyofauna of the Phu Quoc Island (Vietnam), situated in the Gulf of Thailand in the proximity of the coastline of Cambodia, has not been sufficiently studied. The isolation of the island combined with the knowledge on its geological history could yield conclusions on the evolutionary trends and speculations on how individual faunistic groups were formed. The aims of this study were to investigate the recent ichthyofauna of the Phu Quoc Island and to analyze the major evolutionary trends in its history by a comparison with recent faunas of the neighbouring mainland.

Materials and methods. A total of about 4000 fishes representing 97 different teleostean species were collected at 46 sampled sites in the Phu Quoc Island from 6 December 2011 to 12 January 2012 by using different kinds of sampling equipment and collection methods as well as through exploring different habitats. Verification of field species identification and further morphological studies were based on 1290 specimens.

Results. The list of fishes collected in inland waters of the Phu Quoc Island includes 97 species representing 13 orders and 39 families of teleostean species. The majority of these species correspond to the main diagnostic characters of known valid taxa. Two species (Kryptopterus bicirrhis and Brachygobius doriae) demonstrate some differences from their previously recorded diagnostic features, and two cypriniform species significantly differ from their valid congeners and should be described as new taxa.

Conclusion. The major trends in the history of the ichthyofauna of Phu Quoc Island were the elimination of true freshwater stenobiontic species and the progressive development of euryhaline and eurytropic species which replaced former species in seasonally variable biotopes of relatively small tropic island. These eurytropic species are characterized by rather wide morphometric variability and do not demonstrate significant differences in their diagnostic characters comparing the island- and the mainland populations. Two species evolved into separate new taxa during the about 10000 year time interval of the fauna' isolation are characterized by the only common feature-belonging to small short-lived species. As such they were more prone to faster evolutionary changes and the pace of the speciation process. The evolutionary process in fish of the Phu Quoc Island was characterized by weak founder effect and weakly pronounced disruptive selection — producing a low number of evolved species..

Keywords: ichthyofauna, genesis, Phu Quoc Island, speciation

\section{INTRODUCTION}

Studying an island fauna offers a unique opportunity to learn about specific evolutionary trends in different groups of animals and the main features of the genesis of faunas. The comparative analysis of closely related populations living on an island and on the neighbouring mainland may bring about some clues regarding the pace of evolution at different biological levels, starting from the variability of characters and continuing in the origin of new taxa. Therefore, the islands of southeast Asia, repre- senting the largest complex of islands in the world and housing a substantial proportion of global biodiversity (Mittermeier et al. 2004), are of the great interest for both evolutionary- and taxonomic investigators (Heaney 1986, Steppan et al. 2003, Esselstyn et al. 2009). The additional assets of some of those islands are the poorly studied faunas and the sufficiently dated geological history.

The ichthyofauna of the Vietnamese Phu Quoc Island situated in the Gulf of Thailand in the proximity of the Cambodian mainland coast is one of those practically

\footnotetext{
${ }^{*}$ Correspondence: Dr Ekaterina D. Vasil'eva, Zoological Museum, Moscow State University, 125009 Moscow, Russia, phone: +7 495-6294906, fax: +7 495-6294825, e-mail: vas_katerina@mail.ru.
} 
unexplored biodiversities. A preliminary list of the ichthyofauna from the only river of this island (Tram River) includes 22 species (Nezdoly et al. 2005, 2011). The second checklist presented on the site of "Wildlife At Risk" (WAR, a non-profit organization in Delaware, USA) includes 37 freshwater and euryhaline fish species accompanied by photos (Anonymous 2011, unpublished ${ }^{*}$ ): but, the occurrence of five of these 37 listed species have not been confirmed by original findings.

Investigations on the geological evolution of Vietnamese sedimentary basins revealed that the Late Jurassic to Cretaceous Phu Quoc basin (Fyhn et al. 2010, Pedersen et al. 2010) was located in the Gulf of Thailand and continued onshore to the north to form part of the mountainous area between Vietnam and Cambodia. The island and its basin thus shared a common history with the mountainous Cambodian mainland (at first the Cardamom Range) some 150 million years ago. At the height of the last ice age the Gulf of Thailand did not exist; due to the lower sea level, this basin formed part of the Chao Phraya River valley (Emery and Niino 1963, Rainboth 1996). Thus, the histories of the Phu Quoc Island and of the Cambodian mainland could become separated only when the last glacial period ended about 10000 years ago (Kuznetsov and Kuznetsova 2011). This value can be treated as the maximum age of the isolation of the Phu Quoc Island fauna from the Cambodian mainland; although the probability of later colonization by some continental fish populations cannot be completely ruled out.

This study aims to investigate the recent ichthyofauna of the Phu Quoc Island and to analyze the major evolutionary trends in its history by a comparison with recent neighbouring mainland ichthyofaunas.

\section{MATERIALS AND METHODS}

Phu Quoc Island is situated in the Gulf of Thailand, $45 \mathrm{~km}$ from mainland Vietnam and $15 \mathrm{~km}$ south to the coast of Cambodia. The island covers an area of $585 \mathrm{~km}^{2}$, and represents the largest island within an archipelago of 14 islands. It is situated on the shallow continental shelf of the tropical monsoon zone with various geomorphologic and oceanographic conditions. The depth of the sea in this area does not exceed 40-60 m off the southern tip of Phu Qouc, whereas the east shore of the island is characterized by very shallow waters of less than $6 \mathrm{~m}$ that extend $6.4 \mathrm{~km}$ offshore (Otero-Villanueva and Ut 2007). Phu Quoc has a rich variety of marine communities, including patches of coral communities or seagrass, sandy-coarse substrates, groups of small islets, and protected bays.

Inland freshwater systems in Phu Quoc Island are well developed, due to high rainfall (more than $3000 \mathrm{~mm}$ per year) and predominance of the forested area. There are two main river systems in the island: the Cua Can River and the Duong Dong River. The Cua Can River receives water from Chua mountain, its total length is $69 \mathrm{~km}$, and the watershed area is $147 \mathrm{~km}^{2}$. The Duong Dong River starts in Da Bac Mountain, its total length is $63 \mathrm{~km}$, and the watershed area is $105 \mathrm{~km}^{2}$. Other smaller rivers are
Tram, Vung Bau, and $\mathrm{Ca}$; numerous small and short springs form elaborate networks with total high density of $0.42 \mathrm{~km} \times \mathrm{km}^{-2}$ (Anonymous 2006, unpublished ${ }^{* *}$ ). However, the flows are highly variable seasonally, and many small springs completely disappear during the dry season.

The materials for the presently reported study were collected between 6 December 2011 and 12 January 2012 from 46 localities representing different habitats at the Phu Quoc Island (Table 1, Fig. 1). Different sampling equipments and methods were used to collect fish, considering the physical features of each habitat:

- Landing fishing nets with different mouth $(85 \times 45 \mathrm{~cm}$, $45 \times 25 \mathrm{~cm}, 20 \times 40 \mathrm{~cm}$ ), bunt length up to $250 \mathrm{~cm}$ and from 0.5 to $0.1 \mathrm{~cm}$ mesh sizes were used in all shallow habitats; - Gill nets with mesh size 12-25 mm, lift nets with an area $100 \times 100 \mathrm{~cm}$ or, a diameter of about $4 \mathrm{~m}$, hook and line, and benthic shrimp traps for deeper habitats;

- A mosquito net in shallow habitats of several lowland rivers with sandy bottom and slow current. When examining seasonally drying river beds, fish were collected after scooping water from remaining puddles. In addition, specimens were obtained from local fishermen and/or bought from the market in Duong Dong City.

Specimens collected were fixed in $70 \%$ alcohol. The majority of them were deposited in the Southern Branch of the Vietnam-Russian Tropical Center in Ho Chi Minh City, while 1290 specimens with sample numbers from P-22797 to P-23035 and from P-23040 to P-23049 were transferred to the Zoological Museum of the Moscow State University (ZMMU) for verification of field species identification and further morphological analyses.

The identification of the fish species at ZMMU was based on the criteria developed for fishes occurring in neighbouring mainland water systems by Smith (1945) and Rainboth (1996), for gobiid fish by Koumans (1953) and Larson and Murdy (2001), for cobitid fish by Kottelat and Lim (1993), for balitorid fish by Kottelat (1990), for clariid fish by $\mathrm{Ng}$ and Kottelat (2008) and $\mathrm{Ng}$ et al. (2011), for ambassid fish by Allen (1999), for atherinid fish by Ivantsoff and Crowley (1999), for mugilid fish by Harrison and Senou (1999), for haemulid and sillaginid fish by McKay $(1999,2001)$, for clupeid fish by Munroe et al. (1999), for lutjanid fish by Anderson and Allen (2001), for tetraodontid fish by Matsuura (2001), for teraponid fish by Vari (2001), for labrid fish by Westneat (2001), for gerreid and siganid fish by Woodland (2001a, 2001b), for sphyraenid fish by Doiuchi and Nakabo (2005), for ricefishes of the genus Oryzias by Parenti (2008), and for species of the genus Nandus - by Ng et al. (1996) and Chakrabarty et al. (2006). Additional information was obtained from Koumans (1940), Masuda et al. (1984), and Polgar (unpublished ${ }^{* * *}$ ) - for gobiid fishes, and from Kottelat (2001) and Vidthayanon (2008)-for a number freshwater species.

These species were listed in phylogenetic order based on Nelson (2006), using the valid species names from FishBase (Froese and Pauly 2012) and the Catalog of fishes (Eschmeyer 2012). Distribution and ecological data

\footnotetext{
* Anonymous 2011. Preliminary checklist of freshwater fishes of Phu Quoc (13-14/VII/2008, 10-12/VIII/2008). Wildlife at Risk. http://www.wildlifeatrisk.org/new/public.html.

${ }^{* *}$ Anonymous 2006. Ecotourism development strategy of the Phu Quoc National Park, Kien Giang Province (Final draft). Wildlife at risk. University of Agriculture and Forestry, Ho Chi Minh City.

${ }^{* * *}$ Polgar G. 2008. An updated list of the species illustrated in: Herre Albert W. (1927) Monographs of the Bureau of science Manila, Philippine Islands. Monograph 23. Gobies of the Philippines and the China sea. http://www.mudskipper.it/Profile_file/Herre27speciesinplates.pdf.
} 
Sampling localities on Phu Quoc Island

\begin{tabular}{|c|c|c|c|c|c|}
\hline \# & Sampling site & Date & Coordinates & River basin & Habitat types \\
\hline 1 & Ong Dien River & $\begin{array}{l}6 \text { Dec } 2011 \\
\text { and } 4 \text { Jan } 2012\end{array}$ & $10^{\circ} 24.793^{\prime} \mathrm{N} ; 104^{\circ} 01.669^{\prime} \mathrm{E}$ & Ong Dien & $\begin{array}{l}\text { Stagnant backwaters, sandy } \\
\text { freshwater streams, and sandy mouth } \\
\text { with brackish water }\end{array}$ \\
\hline 2 & Bai Dai River & 8 Dec 2011 & $10^{\circ} 21.418^{\prime} \mathrm{N} ; 103^{\circ} 50.600^{\prime} \mathrm{E}$ & Bai Dai & $\begin{array}{l}\text { Remaining pool in dried river-bad in } \\
\text { the forest, and lowland main stream }\end{array}$ \\
\hline 3 & Vung Bau R. & 8 Dec 2011 & $10^{\circ} 20.760^{\prime} \mathrm{N} ; 103^{\circ} 50.879^{\prime} \mathrm{E}$ & Vung Bau & $\begin{array}{l}\text { Lowland river with patches of } \\
\text { vegetation and muddy bottom, } \\
\text { freshwater }\end{array}$ \\
\hline 4 & $\begin{array}{l}\text { Small river after } \\
\text { reservoir }\end{array}$ & 12 Dec 2011 & $10^{\circ} 14.976^{\prime} \mathrm{N} ; 104^{\circ} 01.512^{\prime} \mathrm{E}$ & Duong Dong & $\begin{array}{l}\text { Lowland river with stone or sandy } \\
\text { bottom and patches of vegetation, } \\
\text { freshwater }\end{array}$ \\
\hline 5 & Da Ban stream & 12 Dec 2011 & $10^{\circ} 14.765^{\prime} \mathrm{N} ; 104^{\circ} 01.634^{\prime} \mathrm{E}$ & Duong Dong & $\begin{array}{l}\text { Lowland river with sandy bottom } \\
\text { and small forest stream, both freshwater }\end{array}$ \\
\hline 6 & Tranh stream & 14 Dec 2011 & $10^{\circ} 10.705^{\prime} \mathrm{N} ; 104^{\circ} 00.799^{\prime} \mathrm{E}$ & Cai Lap & $\begin{array}{l}\text { Marshy stream below dried waterfall, } \\
\text { and lowland river with vegetation and } \\
\text { muddy bottom, freshwater }\end{array}$ \\
\hline 7 & Ca River & 14 Dec 2011 & $10^{\circ} 12.403^{\prime} \mathrm{N} ; 104^{\circ} 03.176^{\prime} \mathrm{E}$ & $\mathrm{Ca}$ & $\begin{array}{l}\text { Lowland river mouth with brackish } \\
\text { water }\end{array}$ \\
\hline 8 & Stream at 12 bridge & 16 Dec 2011 & $10^{\circ} 13.875^{\prime} \mathrm{N} ; 104^{\circ} 04.487^{\prime} \mathrm{E}$ & & $\begin{array}{l}\text { Small lowland river with vegetation } \\
\text { and sandy and muddy bottom, } \\
\text { freshwater }\end{array}$ \\
\hline 9 & Cua Can River & 20 Dec 2011 & $10^{\circ} 19.470^{\prime} \mathrm{N} ; 103^{\circ} 58.278^{\prime} \mathrm{E}$ & Cua Can & $\begin{array}{l}\text { Lowland river with sandy bottom } \\
\text { and patches of vegetation, freshwater }\end{array}$ \\
\hline 10 & Tram River & 20 Dec 2011 & $10^{\circ} 22.813^{\prime} \mathrm{N} ; 104^{\circ} 00.448^{\prime} \mathrm{E}$ & Tram & Small hill stream with stone bottom \\
\hline 11 & Tram River & 20 Dec 2011 & $10^{\circ} 22.884^{\prime} \mathrm{N} ; 104^{\circ} 00.279^{\prime} \mathrm{E}$ & Tram & $\begin{array}{l}\text { Lowland river with patches of } \\
\text { vegetation and muddy bottom }\end{array}$ \\
\hline 12 & Stream 1 & 22 Dec 2011 & $10^{\circ} 19.432^{\prime} \mathrm{N} ; 104^{\circ} 02.107^{\prime} \mathrm{E}$ & Cua Can & $\begin{array}{l}\text { Small stream with sandy bottom } \\
\text { and stones and patches of vegetation }\end{array}$ \\
\hline 13 & Stream 2 & 22 Dec 2011 & $10^{\circ} 19.638^{\prime} \mathrm{N} ; 104^{\circ} 01.626^{\prime} \mathrm{E}$ & Cua Can & $\begin{array}{l}\text { Small stream with sandy bottom } \\
\text { and stones and patches of vegetation }\end{array}$ \\
\hline 14 & Stream 3 & 22 Dec 2011 & $10^{\circ} 19.692^{\prime} \mathrm{N} ; 104^{\circ} 00.187^{\prime} \mathrm{E}$ & Cua Can & $\begin{array}{l}\text { Small stream with sandy bottom } \\
\text { and stones and patches of vegetation }\end{array}$ \\
\hline 15 & Stream 4 & 22 Dec 2011 & $10^{\circ} 19.926^{\prime} \mathrm{N} ; 103^{\circ} 59.176^{\prime} \mathrm{E}$ & Cua Can & $\begin{array}{l}\text { Small stream with sandy bottom } \\
\text { and stones and patches of vegetation }\end{array}$ \\
\hline 16 & $\begin{array}{l}\text { Left branch of Tram } \\
\text { River }\end{array}$ & 26 Dec 2011 & $10^{\circ} 22.586^{\prime} \mathrm{N} ; 103^{\circ} 59.008^{\prime} \mathrm{E}$ & Tram & $\begin{array}{l}\text { Forest stream with vegetation and } \\
\text { muddy bottom }\end{array}$ \\
\hline 17 & Small river & 26 Dec 2011 & $10^{\circ} 24.5$ & & Small lowland stream with vegetation \\
\hline 18 & Small river & 26 Dec 2011 & $10^{\circ} 26.391^{\prime} \mathrm{N} ; 104^{\circ} 00.663^{\prime} \mathrm{E}$ & & Mouth of small river, brackish water \\
\hline 19 & Small river & 26 Dec 2011 & $10^{\circ} 26.519^{\prime} \mathrm{N} ; 104^{\circ} 00.585^{\prime} \mathrm{E}$ & & Mouth of small river, brackish water \\
\hline 20 & Small river & 28 Dec 2011 & $10^{\circ} 15.992^{\prime} \mathrm{N} ; 104^{\circ} 00.685^{\prime} \mathrm{E}$ & Duong Dong & $\begin{array}{l}\text { Lowland river with vegetation } \\
\text { and muddy bottom, freshwater }\end{array}$ \\
\hline 21 & Stream & 28 Dec 2011 & $10^{\circ} 16.091^{\prime} \mathrm{N} ; 104^{\circ} 00.875^{\prime} \mathrm{E}$ & Duong Dong & Hill stream with large stones \\
\hline 22 & Tram River & 28 Dec 2011 & $10^{\circ} 24.559^{\prime} \mathrm{N} ; 103^{\circ} 58.190^{\prime} \mathrm{E}$ & Tram & $\begin{array}{l}\text { Lowland river mouth, } \\
\text { brackish water }\end{array}$ \\
\hline 23 & Small river and lake & 28 Dec 2011 & $10^{\circ} 25.046^{\prime} \mathrm{N} ; 104^{\circ} 00.644^{\prime} \mathrm{E}$ & & $\begin{array}{l}\text { Marshy lake and river with dense } \\
\text { vegetation }\end{array}$ \\
\hline 24 & Pond in fore & 28 Dec 2011 & $10^{\circ} 25.110^{\prime} \mathrm{N} ; 104^{\circ} 00.689^{\prime} \mathrm{E}$ & & Deep pond with sandy bottom \\
\hline 25 & Small river & 30 Dec 2011 & $10^{\circ} 17.960^{\prime} \mathrm{N} ; 103^{\circ} 54.546^{\prime} \mathrm{E}$ & & Small river mouth, brackish water \\
\hline 26 & Small river & 30 Dec 2011 & $10^{\circ} 18.354^{\prime} \mathrm{N} ; 103^{\circ} 57.217^{\prime} \mathrm{E}$ & Cua Can & $\begin{array}{l}\text { Lowland river with sandy bottom } \\
\text { and rare vegetation, freshwater }\end{array}$ \\
\hline 27 & Stream & 30 Dec 2011 & $10^{\circ} 19.149^{\prime} \mathrm{N} ; 103^{\circ} 56.954^{\prime} \mathrm{E}$ & Cua Can & $\begin{array}{l}\text { Lowland stream with vegetation } \\
\text { and muddy bottom, freshwater }\end{array}$ \\
\hline 28 & Vem River & 3 Jan 2012 & $10^{\circ} 21.573^{\prime} \mathrm{N} ; 103^{\circ} 56.070^{\prime} \mathrm{E}$ & Vem & $\begin{array}{l}\text { Low part of lowland river with } \\
\text { vegetation and muddy bottom, } \\
\text { brackish water }\end{array}$ \\
\hline 29 & Vem River & 3 Jan 2012 & $10^{\circ} 21.839^{\prime} \mathrm{N} ; 103^{\circ} 55.842^{\prime} \mathrm{E}$ & Vem & Lowland river mouth, brackish water \\
\hline 30 & Vem River & 3 Jan 2012 & $10^{\circ} 21.253^{\prime} \mathrm{N} ; 103^{\circ} 56.190^{\prime} \mathrm{E}$ & Vem & $\begin{array}{l}\text { Lowland river with vegetation and } \\
\text { muddy bottom, freshwater }\end{array}$ \\
\hline
\end{tabular}


Table 1 (cont.)

\begin{tabular}{|c|c|c|c|c|c|}
\hline \# & Sampling site & Date & Coordinates & River basin & Habitat types \\
\hline 31 & Cua Can flood & 3 Jan 2012 & $10^{\circ} 19.840^{\prime} \mathrm{N} ; 103^{\circ} 57.930^{\prime} \mathrm{E}$ & Cua Can & $\begin{array}{l}\text { Lowland river flood with dense } \\
\text { vegetation and muddy bottom }\end{array}$ \\
\hline 32 & Small river & 3 Jan 2012 & $10^{\circ} 16.109^{\prime} \mathrm{N} ; 103^{\circ} 57.732^{\prime} \mathrm{E}$ & Duong Dong & $\begin{array}{l}\text { Small dried lowland river with sandy } \\
\text { bottom, freshwater }\end{array}$ \\
\hline 33 & Small river & 3 Jan 2012 & $10^{\circ} 13.677^{\prime} \mathrm{N} ; 103^{\circ} 59.395^{\prime} \mathrm{E}$ & Duong Dong & Small forest river, freshwater \\
\hline 34 & Small river & 4 Jan 2012 & $10^{\circ} 24.409^{\prime} \mathrm{N} ; 104^{\circ} 01.779^{\prime} \mathrm{E}$ & & Hill stream with large stones \\
\hline 35 & Small river & 4 Jan 2012 & $10^{\circ} 24.744^{\prime} \mathrm{N} ; 104^{\circ} 01.972^{\prime} \mathrm{E}$ & & $\begin{array}{l}\text { Small lowland river mouth, } \\
\text { brackish water }\end{array}$ \\
\hline 36 & River at 35 bridge & 4 Jan 2012 & $10^{\circ} 24.239^{\prime} \mathrm{N} ; 104^{\circ} 02.972^{\prime} \mathrm{E}$ & & $\begin{array}{l}\text { Low part of small lowland river, } \\
\text { brackish water }\end{array}$ \\
\hline 37 & River at 34 bridge & 4 Jan 2012 & $10^{\circ} 24.133^{\prime} \mathrm{N} ; 104^{\circ} 03.112^{\prime} \mathrm{E}$ & & $\begin{array}{l}\text { Low part of lowland river, sandy } \\
\text { bottom with large stones, brackish water }\end{array}$ \\
\hline 38 & Dam River & 6 Jan 2012 & $10^{\circ} 03.900^{\prime} \mathrm{N} ; 104^{\circ} 01.125^{\prime} \mathrm{E}$ & Dam & Lowland river mouth, brackish water \\
\hline 39 & Dam River & $\begin{array}{l}6 \text { and } 12 \text { Jan } \\
2012\end{array}$ & $10^{\circ} 04.253^{\prime} \mathrm{N} ; 104^{\circ} 00.294^{\prime} \mathrm{E}$ & Dam & $\begin{array}{l}\text { Low part of lowland river, } \\
\text { brackish water }\end{array}$ \\
\hline 40 & River at 15 bridge & 10 Jan 2012 & $10^{\circ} 21.242^{\prime} \mathrm{N} ; 103^{\circ} 52.147^{\prime} \mathrm{E}$ & & Hill stream with large stones \\
\hline 41 & Cai Lap River & 11 Jan 2012 & $10^{\circ} 10.417^{\prime} \mathrm{N} ; 103^{\circ} 58.239^{\prime} \mathrm{E}$ & Cai Lap & $\begin{array}{l}\text { Low part of lowland river, } \\
\text { brackish water }\end{array}$ \\
\hline 42 & Cai Lap River & 11 Jan 2012 & $10^{\circ} 10.577^{\prime} \mathrm{N} ; 103^{\circ} 58.602^{\prime} \mathrm{E}$ & Cai Lap & $\begin{array}{l}\text { Low part of lowland river } \\
\text { in a forest, brackish water }\end{array}$ \\
\hline 43 & Stream & 11 Jan 2012 & $10^{\circ} 09.004^{\prime} \mathrm{N} ; 103^{\circ} 58.640^{\prime} \mathrm{E}$ & Cai Lap & $\begin{array}{l}\text { Small river with vegetation and } \\
\text { muddy bottom, freshwater }\end{array}$ \\
\hline 44 & Small river & 11 Jan 2012 & $10^{\circ} 02.778^{\prime} \mathrm{N} ; 103^{\circ} 59.940^{\prime} \mathrm{E}$ & & $\begin{array}{l}\text { Small lowland river mouth, } \\
\text { brackish water }\end{array}$ \\
\hline $45^{\circledR}$ & Duong Dong River & & $10^{\circ} 12.899^{\prime} \mathrm{N} ; 103^{\circ} 57.717^{\prime} \mathrm{E}$ & Duong Dong & $\begin{array}{l}\text { Low part of large lowland river, } \\
\text { brackish water }\end{array}$ \\
\hline $46^{\circledR}$ & Duong Dong River & & $10^{\circ} 12.999^{\prime} \mathrm{N} ; 103^{\circ} 58.855^{\prime} \mathrm{E}$ & Duong Dong & $\begin{array}{l}\text { Low part of large lowland river, } \\
\text { brackish water }\end{array}$ \\
\hline
\end{tabular}

${ }^{\circledR}$ Sampling was carried out repeatedly.
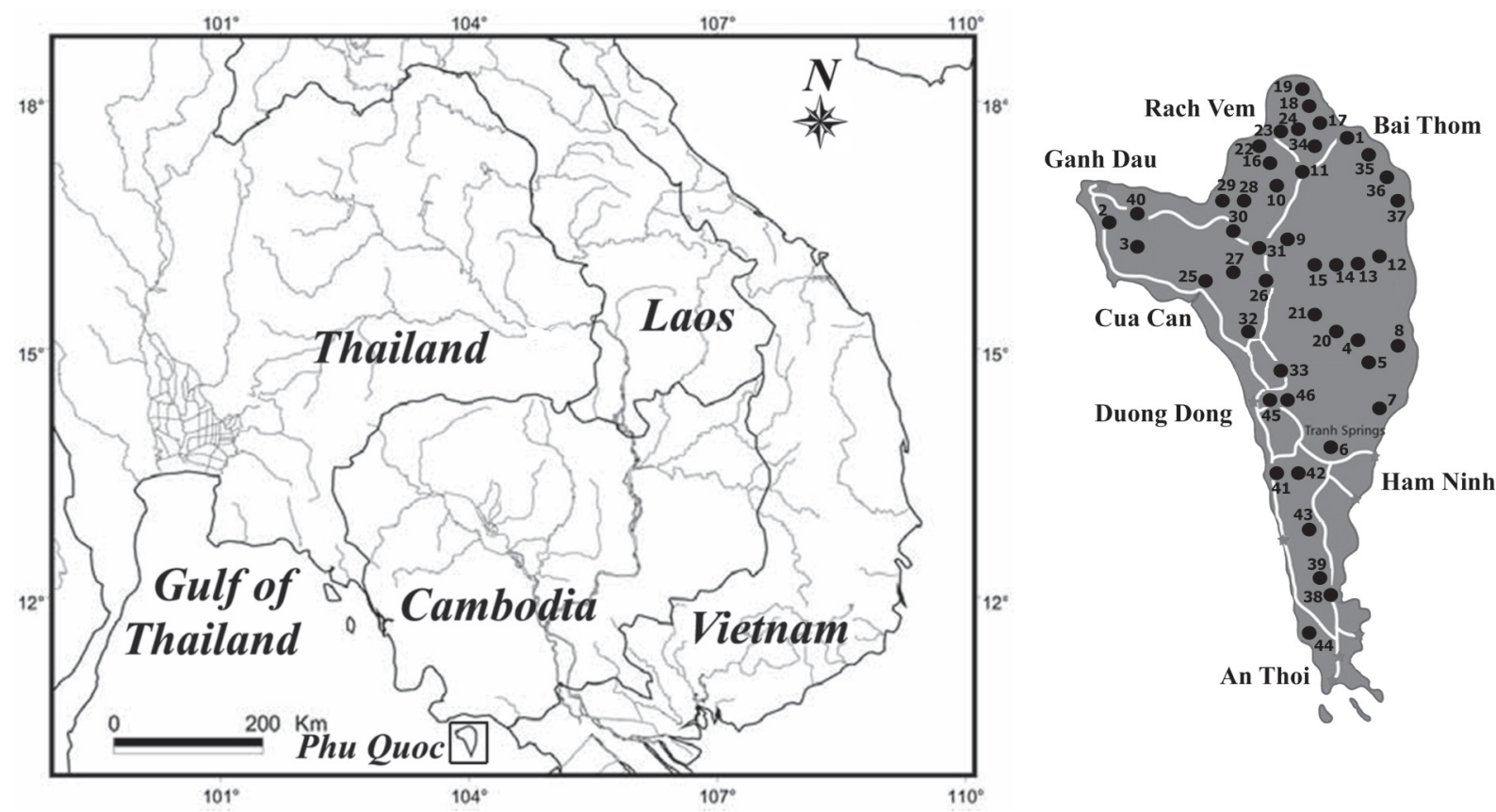

Fig. 1. Map of the Cambodian coastline showing location of the Phu Quoc Island and fish sampling sites (see locality details corresponding to station numbers in Table 1) 
were obtained from FishBase (Froese and Pauly 2012) and from the aforementioned literature used for fish identification. For each species, this list includes: the valid scientific name, the common name (favoured by FishBase), the salinity category of aquatic habitat where the species is found, the geographical distribution, the data on the collected material (including local site numbers defined in Table 1 and Fig. 1), the main diagnostic features of the specimens used in their identification, and the commonly used morphological characters: fish total length (TL) fish standard length SL, and ray counts of dorsal $(D)$, anal $(A)$, pectoral $(P)$, and pelvic $(V)$ fins. The number of spines or unsegmented (simple) fin rays is expressed by Roman numerals, and the number of soft or branched rays - by Arabic numerals. Since the last two branched dorsal and anal rays are often borne by a single pterygophore, these two rays are counted as ' $1 \frac{1}{2}$ '.

\section{RESULTS AND DISCUSSION}

We started our research in the Phu Quoc Island in the early dry season, when some river parts were represented by a disconnected chain of residual pools, sheltered by the forest, while the others were becoming more accessible for sampling due to the lowering of the water. We collected about 4000 fish specimens representing 97 species, 13 orders, and 39 families (Annotated checklist_-below). During our research, we also observed (but not succeeded in sampling) some additional fish species in brackish water of lower river parts, usually used as feeding areas by schools of marine fish juveniles. Thus, we believe that the real number of the species populating inland waters of the island is about 100 . The same estimations were given by experts related with the WAR, who have been studying the ichthyofana of the island since July 2008 (Anonymous 2011, unpublished*). Therefore, we presume that our data are representative for the analysis of recent structure of the fish fauna of the island and the main trends in its evolution. For further analysis we excluded the African exotic Oreochromis niloticus, and used the value of 96 native species as the basic estimate of revealed biodiversity.

Annotated checklist of fishes in inland waters of the Phu Quoc Island

ORDER OSTEOGLOSSIFORMES (bonytongues)

FAMILY NOTOPTERIDAE (featherfin knifefishes)

Notopterus notopterus (Pallas, 1769) (bronze featherback)

Distribution: Fresh- and brackish waters. Asia: Indus, Ganges-Brahmaputra, Mahanadi, Krishna, Cauvery, and other river basins in southern India; Irrawaddy, and Salween; Maeklong, Chao Phraya, Mekong and virtually all coastal river basins of peninsular Thailand and Malaysia; Sumatra and Java (Roberts 1992, Kottelat 2001, Riede unpublished**). Phu Quoc: Duong Dong River drainage (collected by local fishermen).

Specimens: $n=6 ; 77-145 \mathrm{~mm}$ TL.

Diagnosis: Long anal fin with 97-110 soft rays originating just behind pelvic fins and continuing with caudal fin; humped back; plain brownish adult.
ORDER ELOPIFORMES (tenpounders)

FAMILY MEGALOPIDAE (tarpons)

Megalops cyprinoides (Broussonet, 1782) (Indo-Pacific tarpon)

Distribution: Marine-, fresh-, and brackish waters; Indo-Pacific (Smith 1986, Allen 1991); Phu Quoc: Dam River (site \#38).

Specimens: $n=2$; 97-106 mm TL.

Diagnosis: $D$ 16-21; $A$ 23-31; abdominal pelvic fins with 9-11 rays; lower jaw projecting beyond snout; bony gular plate present between jaw bones; last dorsal-fin ray long and filamentous; pectoral fins ventrally located; blue-green dorsally, silvery on sides.

\section{ORDER CLUPEIFORMES (herrings)}

FAMILY CLUPEIDAE (herrings)

Hilsa kelee (Cuvier, 1829) (kelee shad)

Distribution: Marine-, fresh-, and brackish waters; Indo-West Pacific (Munroe et al. 1999, Riede unpublished*); Phu Quoc: Dam River (\# 39).

Specimens: $n=1 ; 43 \mathrm{~mm}$ TL.

Diagnosis: Upper jaw with median notch when seen from front; mouth terminal; top of head with numerous fronto-parietal striae.

Nematalosa galatheae Nelson et Rothman, 1973 (galathea gizzard shad)

Distribution: Marine-, fresh-, and brackish waters; Indo-West Pacific (Munroe et al. 1999, Riede unpublished*); Phu Quoc: Duong Dong River (\# 45).

Specimens: $n=1 ; 65 \mathrm{~mm}$ TL (without posterior parts of dorsal and anal fins).

Diagnosis: Body depth 38.4\% SL; upper jaw with distinct median notch when seen from front; mouth inferior; lower jaw flared outward; predorsal scales paired and overlapping in midline; anterior arm of preopercle with third infraorbital bone immediately above it; pair of grooves on top of head, hidden in skin; posterior edge of scales not toothed.

Sardinella fimbriata (Valenciennes, 1847) (fringescale sardinella)

Distribution: Marine- and brackish waters; Indo-West Pacific (Munroe et al. 1999); Phu Quoc: Duong Dong River (\# 46).

Specimens: $n=2$; 94-102 mm TL.

Diagnosis: $V$ I 7; upper jaw round when seen from front; both anterior and posterior supramaxilla present; opercle smooth; posterior border of gill opening with two distinct fleshy outgrowths; two posterior anal-fin rays elongate; body compressed; abdomen keeled; vertical striae on scales discontinuous, not meeting at centre; hind part of scales with few perforations; dark spot at dorsal fin origin. ORDER GONORYNCHIFORMES (milkfishes)

FAMILY CHANIDAE (milkfishes)

Chanos chanos (Forsskål, 1775) (milkfish)

Distribution: Marine-, fresh-, and brackish waters; Indo-Pacific (Bagarinao 1994, Riede unpublished*); Phu Quoc: Ca River mouth (\# 7).

${ }^{* *}$ Riede K. 2004. Global register of migratory species—-from global to regional scales. Final Report of the R\&D-Projekt 80805081 . Federal Agency for Nature Conservation, Bonn, Germany.
} 
Specimens: $n=1 ; 560 \mathrm{~mm}$ TL.

Diagnosis: $D$ 15; $A$ 10; fins without spines; body elongate and somewhat compressed; mouth small, terminal, and toothless; axillary scales above and below pectoral and pelvic fins; no scutes along belly; caudal fin deeply forked; body olive green; flanks silvery; fins dark bordered.

\section{ORDER CYPRINIFORMES (carps)}

FAMILY CYPRINIDAE (minnows or carps) Barbonymus gonionotus (Bleeker, 1849) (silver barb)

Distribution: Freshwater; Asia-Mekong and Chao Phraya basins, Malay Peninsula, Sumatra, and Java; occurs throughout the whole stretch of the Mekong, from the delta around the saline intrusion zone to Chiang Khong in Thailand (Kottelat 1998, Sokheng et al. unpublished*); Phu Quoc: Duong Dong River drainage (purchased on the market).

Specimens: $n=1 ; 260 \mathrm{~mm}$ TL.

Diagnosis: $D$ IV 8; $A$ III 6; last simple dorsal ray spinous and serrated; body strongly compressed; back arched; head small; snout pointed; mouth terminal; barbels very minute, less than $1 / 4$ eye diameter; body silvery white; dorsal and caudal fins grey; anal- and pelvic fins light yellow, their tips reddish.

Cyclocheilichthys apogon (Valenciennes, 1842) (beardless barb)

Distribution: Freshwater; Asia-Myanmar to Indonesia (Rainboth 1996); Phu Quoc: Duong Dong (\# 4) and Cua Can (\# 12) river drainages.

Specimens: $n=3 ; 37-47 \mathrm{~mm}$ TL.

Diagnosis: $D$ III $8 \frac{1}{2} ; A$ III $5 \frac{1}{2}$; last simple dorsal ray spinous and serrated; no sharp keel in front of pelvic; head with numerous rows of pores forming parallel rows; lateral line complete, 34-35 pored scales; no barbels; black blotch at caudal fin base; rows of black spots along scale rows.

\section{Danio albolineatus (Blyth, 1860) (pearl danio)}

Distribution: Freshwater; Asia-Myanmar to Laos and the island of Sumatra, Indonesia; reported from Irrawaddy-, Salween-, Mekong-, Maeklong drainages (Fang and Kottelat 1999, Kottelat 2001); Phu Quoc: the majority of the studied freshwater sites all over the island and a few sites with brackish water (\#2-6, 9-18, 20, 21, 26, 27, 30, 32, 34, 37, 40).

Specimens: $n=18 ; 20-40 \mathrm{~mm}$ TL.

Diagnosis: $D$ II 71/2; $A$ III $11 \frac{1}{2}-14 \frac{1}{2}$; last simple dorsal ray non-spinous; no sharp keel in front of pelvic; dorsal origin behind pelvic origin; incomplete lateral line with 4-10 pored scales, ending before pelvic fin base; two pairs of long barbels; rostral barbel reaching to or slightly anterior to vertical through middle of orbit; maxillary barbel exceeding origin of pectoral fin; two orange longitudinal stripes (upper one from head to caudal fin base and less prominent lower one) separated and bordered with bluish stripes (all iridescent in live specimen).

Esomus metallicus Ahl, 1923 (striped flying barb)

Distribution: Fresh- and brackish waters; Asia-
Mekong-, Salween-, and Chao Phraya basins, also from the northern Malay Peninsula (Kottelat 2001); Phu Quoc: Cua Can River drainage (\# 26).

Specimens: $n=10 ; 45-54 \mathrm{~mm}$ TL.

Diagnosis: $D$ II $6 \frac{1}{2}-7$; $A$ II $5 \frac{1}{2}-6$; abdomen in front of pelvic origin rounded; lateral line incomplete; two pairs of barbels; anterior (rostral) barbels relatively short, extending at most to posterior margin of eye; maxillary barbels reaching past pelvic fins; prominent black mid-lateral stripe on body from eye to caudal fin base.

\section{Osteochilus vittatus (Valenciennes, 1842) (bonylip barb)}

Distribution: Freshwater; Asia-Mekong- and Chao Phraya basins, Malay Peninsula, Sumatra, Java and Borneo; reported from Salween- and Maeklong basins (Vidthayanon et al. 1997, Kottelat 1998); Phu Quoc: Duong Dong and Cua Can river drainages (\# 4, 5, 12, 14, 33).

Specimens: $n=5 ; 38-95 \mathrm{~mm}$ TL.

Diagnosis: $D$ III $16^{1 / 2-19 \frac{1}{2} ; A}$ III $5 \frac{1}{2}-6$; last simple dorsal fin ray non-spinous; no sharp keel in front of pelvic; complete lateral line with 32-33 pored scales; two pairs of short barbels; large round blotch on caudal peduncle; all fins reddish.

\section{Parachela maculicauda (Smith, 1934)}

Distribution: Freshwater; Asia-Mekong- and Chao Phraya basins, Malay Peninsula and Sumatra; reported from the Maeklong basin (Vidthayanon et al. 1997, Kottelat 2001); Phu Quoc: Cua Can River drainage (\# 9, 26).

Specimens: $n=9$; 17-32 mm TL.

Diagnosis: $D$ II 7; $A$ II 25-26; belly with sharplyedged keel; epaxial musculature reaching interorbital space; dorsal-fin origin almost above anal-fin origin; lateral line with not more than 40 pored scales; subterminal black blotches on caudal-fin lobes.

Puntius binotatus (Valenciennes, 1842) (spotted barb)

Distribution: Freshwater; Asia-Myanmar and from Mekong of Thailand through Indonesia (Rainboth 1996); Phu Quoc: the majority of the studied freshwater sites all over the island (\# 1, 2, 4, 6, 8-14, 20, 21, 26, 39, 40) and the only site with brackish water (\# 37).

Specimens: $n=27$; 20-130 mm TL.

Diagnosis: $D$ III 8-81/2; $A$ III 5-6, $V$ I 8; last simple dorsal fin ray serrated; two pairs of barbels; complete lateral line with 24-27 pored scales; 9-10 predorsal scales; black spot immediately below dorsal-fin origin (always present), one on middle of caudal peduncle at caudal-fin base and another black spot above anal fin, in some specimens both last spots absent; juveniles having several small spots along lateral line.

Rasbora aurotaenia Tirant, 1885 (pale rasbora)

Distribution: Freshwater; Asia-Chao Phraya- and Mekong basins; reported from Maeklong River (Rainboth 1996, Vidthayanon et al. 1997); Phu Quoc: Cua Can River drainage (\# 9, 12-14, 26).

Specimens: $n=34 ; 26-52 \mathrm{~mm}$ TL.

Diagnosis: $D$ II $7 \frac{1}{2}$; $A$ III $5 \frac{1}{2}-6$; last simple dorsal fin

\footnotetext{
* Sokheng C., Chhea C.K., Viravong S., Bouakhamvongsa K., Suntornratana U., Yoorong N., Tung N.T., Bao T.Q., Poulsen A.F., Jørgensen J.V. 1999. Fish migrations and spawning habits in the Mekong mainstream: a survey using local knowledge (basin-wide). Assessment of Mekong fisheries: Fish Migrations and Spawning and the Impact of Water Management Project (AMFC). AMFP Report 2/99. Vientiane, Lao, P.D.R.
} 
ray non-spinous; lateral line complete, with 24-27 pored scales; 11-12 predorsal scale rows; 2 scale rows between lateral line and mid-ventral scale rows; body depth 3.2-3.7 times in SL; no sharp keel in front of pelvic; conspicuous symphysal knob on lower jaw fitting into depression of upper jaw; mouth small, terminal; no barbels; dorsal origin behind pelvic origin; pale in colour with distinctive neon stripe running above dark mid-lateral band in living specimens; caudal fin bright yellow; after fixation lateral stripe from opercle to caudal fin base silver in anterior part and grey in posterior, not widening to caudal fin base.

\section{Rasbora paviana Tirant, 1885 (sidestripe rasbora)}

Distribution: Freshwater; Asia-Mekong-, Chao Phraya-, and Maeklong basins; also from northern Malay Peninsula (Rainboth 1996); Phu Quoc: the majority of the studied freshwater sites all over the island (\# 1-3, 5, 6, 8-17, 20, 26-27, 34, 40, 43) and a few places with brackish water (\# 18, 22, 28, 36, 37, 39, 42).

Specimens: $n=51 ; 25-95 \mathrm{~mm}$ TL.

Diagnosis: $D$ II $7-7 \frac{1}{2} ; A$ III 51/2-6; last simple dorsal fin ray non-spinous; lateral line complete, $27-30$ pored scales; 11-12 predorsal scales; 41/2 scale rows between dorsal-fin origin and lateral line; no sharp keel in front of pelvic; conspicuous symphysal knob on lower jaw fitting into depression of upper jaw; mouth small, terminal; no barbels; scale margins outlined by reticulated dark pattern; conspicuous, narrow, black longitudinal stripe along sides, widening into diamond-shaped blotch on caudal peduncle.

\section{Rasbora sp.}

Distribution: Freshwater; Phu Quoc - the majority of the freshwater sites all over the island (\# 1-6, 12-15, 17, 20, 23, 24, 26, 27, 30, 31, 43).

Specimens: $n=40 ; 23-39 \mathrm{~mm}$ TL.

Diagnosis: $D$ II $7-7 \frac{1}{2} ; A$ II $5 \frac{1}{2}$; last simple dorsal fin ray non-spinous; no sharp keel in front of pelvic; conspicuous symphysal knob on lower jaw fitting into depression of upper jaw; mouth small, terminal; no barbels; incomplete lateral line with 4-7 pored scales, not reaching pelvic fin origin; dark brown mid-lateral stripe from gill opening to caudal fin base, not widening posteriorly; no red coloration on fins and body.

Rasbora trilineata Steindachner, 1870 (three-lined rasbora)

Distribution: Freshwater; Asia-Mekong- and Chao Phraya basins; Malay Peninsula, Sumatra, Borneo (Kottelat 2001); spread around the world through the aquarium fish trade; recorded for Mekong delta (Vidthayanon 2008); Phu Quoc: Duong Dong and Cua Can River drainages (\#4, 5, 9, 12-15, 26).

Specimens: $n=47 ; 45-63 \mathrm{~mm}$ TL.

Diagnosis: $D$ II $7 \frac{1}{2} ; A$ III 51/2-6; last simple dorsal fin ray non-spinous; $12-13$ predorsal scale rows; no sharp keel in front of pelvic; conspicuous symphysal knob on lower jaw fitting into depression of upper jaw; mouth small, terminal; no barbels; dorsal fin origin slightly behind pelvic fin origin; short blackish line present on each side along base of anal fin; line on both sides uniting behind anal fin and extending to base of caudal fin along lower edge of caudal peduncle; narrow dark mid-lateral stripe on side; black stripe along middle of back; each caudal lobe crossed by black subterminal stripe; no red coloration on caudal fin.

Trigonostigma espei (Meinken, 1967) (lambchop rasbora)

Distribution: Freshwater; Asia-Thailand, Laos, Cambodia, Vietnam (Kottelat and Witte 1999); Phu Quoc: the majority of the studied freshwater sites in the northern and central parts of the island (\# 2-4, 6, 12, $14-15,20,30,31)$; was not found in fresh waters in the southern part.

Specimens: $n=39 ; 16-32 \mathrm{~mm}$ TL.

Diagnosis: D II 7-71/2; A III 51/2-6; last simple dorsal fin ray non-spinous; lateral line incomplete with 4-8 pored scales; 11 predorsal scale rows; no sharp keel in front of pelvic; conspicuous symphysal knob on lower jaw fitting into depression of upper jaw; mouth small, terminal; no barbels; dorsal fin origin behind pelvic fin origin; lambchop-shaped black blotch on caudal peduncle.

\section{FAMILY COBITIDAE (loaches)}

Lepidocephalichthys furcatus (de Beaufort, 1933)

Distribution: Freshwater; Malay Peninsula, Mekong and Chao Phraya basins (Laos, Thailand) (Kottelat 2001); Phu Quoc: the majority of the studied freshwater sites in the northern and central parts of the island (\# 2-4, 9, 23, $24,26,27,30,31)$; was not found in fresh waters of the southern part.

Specimens: $n=69 ; 25-38 \mathrm{~mm}$ TL.

Diagnosis: $D$ II-III $6 \frac{1}{2}-7 \frac{1}{2}, A$ II-III $5 \frac{1}{2}$; body elongate; origin of dorsal fin above- or slightly in front of pelvic fin origin; suborbital spine present; 6 barbels; forked caudal fin; large vertically oriented, semicircular plate on pectoral rays 7-8 of male; dark " $<$ "- shaped mark at caudal fin base.

\section{Lepidocephalichthys hasselti (Valenciennes, 1846)}

Distribution: Freshwater; Asia-Thailand to Vietnam and Indonesia (Kottelat 2001); Phu Quoc: Ong Dien River (\# 1-2, specimens lacking caudal fin) and Da Ban Stream (\# 5).

Specimens: $n=3 ; 21-23 \mathrm{~mm}$ SL.

Diagnosis: $D$ II $6 \frac{1}{2}$; $A$ II $5 \frac{1}{2}$; body elongate; origin of dorsal fin slightly behind pelvic fin origin; suborbital spine present; 6 barbels; caudal fin truncate; 10 brown saddles on back; small black spot at base of first dorsal ray; median longitudinal row of adjacent black spots on body; caudal fin with 5-6 irregular bars.

Pangio kuhlii (Valenciennes, 1846) (coolie loach)

Distribution: Freshwater; Asia-Indonesia, Malaysia, Thailand (Kottelat and Lim 1993); firstly recorded for Vietnam from the Phu Quoc Island (our previous unpublished data); Phu Quoc: Duong Dong and Cua Can river drainages (\# 4, 9, 13, 15, 26).

Specimens: $n=27$; 29-70 mm TL. 
Diagnosis: Body elongate; suborbital spine present; 6 barbels; dorsal origin well behind pelvic fin base; usually 10 dark large almost rectangular bars across brownish orange body; posterior rim of anterior nostril not produced into nasal barbel, its length not exceeding length of eye horizontal diameter; caudal fin with large black basal blotch.

\section{FAMILY BALITORIDAE (river loaches)}

\section{Barbucca sp.}

Distribution: Freshwater; Phu Quoc: Cua Can River drainage (\# 9, 12, 13, 26).

Specimens: $n=17$; 19-34 mm TL.

Diagnosis: $P$ I 91/2-10; $V$ I 6; anterior part of body compressed; cross section semi-circular, becoming more oval behind dorsal-fin origin; head depressed; mouth inferior and strongly arched; lower lip with wide median interruption forming two lateral rounded smooth pads; breeding tubercles on caudal peduncle and cheeks; living specimens brown with 11-12 dark blackish vertical bars usually completely confluent into six large blotches separated by narrow lighter interspaces; glowing red eyes.

\section{ORDER SILURIFORMES (catfishes)}

FAMILY AMBLYCIPITIDAE (torrent catfishes)

Amblyceps mangois (Hamilton, 1822) (Indian torrent catfish)

Distribution: Freshwater; Asia-Pakistan to Thailand (Rainboth 1996); Phu Quoc: stream from the Cua Can River drainage (\# 13).

Specimens: $n=4 ; 41-57 \mathrm{~mm}$ TL.

Diagnosis: $D$ I 6; anal fin with 10 rays (total); body depth (before dorsal fin) $11.6 \%-17.7 \%$ SL; spines in dorsal- and pectoral fins weak and hidden in thick skin; pectoral spine smooth; nostrils close to each other, separated only by nasal barbel; eyes small, covered with skin; adipose fin present; upper caudal fin lobe apparently longer than lower one; body brownish; upper parts of dorsal-, anal-, and paired fins light.

FAMILY AKYSIDAE (stream catfishes) Akysis ephippifer $\mathrm{Ng}$ et Kottelat, 1998

Distribution: Freshwater; Asia-Xe Kong basin in Laos, Cambodia (Kottelat 2001); Phu Quoc: Cua Can River drainage $(\# 9,15)$ and Vem River (\# 30).

Specimens: $n=6 ; 26-40 \mathrm{~mm}$ TL.

Diagnosis: $D$ I 5; $A$ I-III 7-81/2 (totally 9-10 rays); depth of caudal peduncle $10.3 \%-12.9 \% \mathrm{SL}$; dorsal fin with pungent spine; adipose fin present; posterior nostril with barbel, its length shorter than head length; head and body rugose, covered by tubercles; enough round head when viewed dorsally; 4-6 strong serrae on posterior edge of pectoral spine; caudal fin emarginate; large irregular dark blotches on sides, dorsal and caudal fins.

\section{FAMILY SILURIDAE (sheatfishes)}

Kryptopterus bicirrhis (Valenciennes, 1840) (glass catfish)

Distribution: Freshwater; Asia-Mekong and Chao Phraya basins; Malay Peninsula, Sumatra and Borneo
(Kottelat 1998); Phu Quoc: several freshwater sites in the northern and central parts of the island (\# 4, 13, 16, 24, 27). Specimens: $n=16$; 40-83 mm TL.

Diagnosis: 49-54 anal rays; 11-12 gill rakers on first gill arch; dorsal fin spineless, rudimentary, with single ray; head width $11.4 \%-12.3 \%$ SL; body depth at anus $20.9 \%-21.0 \%$ SL; eye diameter $25.8 \%-29.2 \%$ head length; no adipose fin; maxillary barbels reaching to anal fin; mandibular barbels shorter than eye; dorsal profile arched.

\section{Silurichthys hasseltii Bleeker, 1858}

Distribution: Freshwater; Asia-Malaysia, Singapore and Indonesia; known from the Mekong basin ( $\mathrm{Ng}$ and $\mathrm{Ng}$ 1998); Phu Quoc: the majority of the studied freshwater sites in the northern and central parts of the island (\# 2, 5, $6,9,11,12,15,17,21,30)$.

Specimens: $n=21 ; 46-108 \mathrm{~mm}$ TL.

Diagnosis: $D$ 4; $A$ 58-62; P I 10-11; V I 6-7; 12 principal caudal fin rays; dorsal fin spineless; medial anal fin rays often longer than body depth where they attach; anal fin completely confluent with caudal fin; eyes subcutaneous, behind corner of mouth; two pairs of barbels; dorsal-fin origin slightly in front of pelvic-fin origin; caudal fin asymmetrical, with upper lobe slightly longer than lower lobe; body dark brown; fins grey.

\section{FAMILY CLARIIDAE (airbreathing catfishes)}

Clarias gracilentus Ng, Hong et Tu, 2011

Distribution: Freshwater; The species was described from the Phu Quoc Island (Tram and Vem River drainages) and Kampot River (southern Cambodia) (Ng et al. 2011); according to our data also occurs in the Cua Can River drainage (collected by local fishermen) and Bai Dai River (\# 2).

Specimens: $n=5 ; 142-317 \mathrm{~mm}$ TL.

Diagnosis: $D$ 82-94; $A$ 73-82; greatly elongate body with correspondingly long dorsal- and anal fin bases, more or less confluent with caudal fin; anterior edge of pectoral spine with series of small serrations; $13-15$ vertical rows of white spots on lower sides of body.

Clarias macrocephalus Günther, 1864 (bighead catfish)

Distribution: Fresh- and brackish waters; AsiaThailand to Vietnam; introduced to China, Malaysia, Guam, and the Philippines (Ng and Kottelat 2008); Phu Quoc: collected in the Cua Can River drainage by local fishermen; found in several sites with fresh- or brackish waters from different parts of the island (\# 1, 17, 43).

Specimens: $n=7 ; 125-284 \mathrm{~mm}$ TL.

Diagnosis: $D$ 58-68; $A$ 47-50; short, wide and rounded occipital process, its length $2.8-4.0$ times in its width; distance between dorsal and occipital process 6.0-8.7 times in distance from tip of snout to end of occipital process, 3.3\%-5.7\% SL; head length 3.3-3.6 times in SL $(23.3 \%-30.6 \% \mathrm{SL})$; anterior edge of pectoral spine not strongly serrated, usually rugose.

Clarias meladerma Bleeker, 1846 (blackskin catfish)

Distribution: Freshwater; Asia-Mekong to Indonesia 
and the Philippines (Ng and Kottelat 2008); Phu Quoc: several studied freshwater sites in the northern and central parts of the island (\# 2, 5, 6, 12, 14, 31).

Specimens: $n=17 ; 31-212 \mathrm{~mm}$ TL.

Diagnosis: $D$ 66-74; $A$ 53-58; head length (from tip of snout to extremity of occipital process) $3.9-4.3$ times in SL; distance between occipital process and dorsal fin $3.3 \%-5.4 \% \mathrm{SL}$; anterior edge of pectoral spine strongly serrated; blackish body.

\section{FAMILY PANGASIIDAE (shark catfishes)}

Pangasianodon gigas Chevey, 1931 (Mekong giant catfish)

Distribution: Freshwater; Endemic to the Mekong basin where it has become rare due to overexploitation; introduced into additional river basins for aquaculture; native in Vietnam (Kottelat 2001); Phu Quoc: Duong Dong River drainage (purchased on the market).

Specimens: $n=1 ; 460 \mathrm{~mm}$ TL.

Diagnosis: $D$ II 7; $A$ VI 30; $P$ I 7; body without stripes; posterior nostril located near anterior nostril; maxillary barbels very short, shorter than eye diameter; mandibular barbels rudimentary.

FAMILY BAGRIDAE (bagrid catfishes)

Hemibagrus nemurus (Valenciennes, 1840) (Asian redtail catfish)

Distribution: Fresh- and brackish waters; AsiaMekong-, Chao Phraya- and Xe Bangfai basins; also from the Malay Peninsula, Sumatra, Java, and Borneo (Rainboth 1996, Kottelat 2001); Phu Quoc: Duong Dong River drainage (purchased on the market).

Specimens: $n=2 ; 191-215 \mathrm{~mm}$ TL.

Diagnosis: $D$ II 7; $A$ III 9-10; 4 pairs of barbels; nasal barbels extending to about middle of eyes, maxillary ones extending to origin of anal fin, mandibular ones beyond base of pectoral fins, and mental barbels extend to 2/3-3/4 distance between their base and insertion of pectoral fins; base of adipose fin shorter than that of dorsal fin and about equal to that of anal fin; depressed dorsal fin not reaching adipose fin; head flattened rather than conical; rugose skull roof; pectoral fin spines serrated along inner edge and with minute serration in front; upper lobe of caudal fin elongate in filamentous; body brown, often with greenish sheen; black blotch on posterior part of adipose fin.

\section{Hemibagrus planiceps (Valenciennes, 1840)}

Distribution: Freshwater; Asia-Sumatra and Java, Indonesia; reported from the Mekong basin (Taki 1974, Kottelat et al. 1993); Phu Quoc: Duong Dong River drainage (purchased on the market).

Specimens: $n=1 ; 95 \mathrm{~mm}$ TL.

Diagnosis: $D$ II 7; $A$ III 10; maxillary barbels reaching to anal fin origin; adipose fin short, apparently shorter than anal fin base; dorsal spine ossified and serrated on posterior edge; dorsal fin depth about equal to body depth; short occipital process not close to basal bone of dorsal fin; body brownish, no stripes.
Mystus gulio (Hamilton, 1822) (long whiskers catfish)

Distribution: Fresh- and brackish waters; Asia — countries bordering the eastern Indian Ocean, from India to Indonesia and Vietnam (Smith 1945); Phu Quoc: Dam River (\# 39).

Specimens: $n=3$; 60-66 mm TL.

Diagnosis: 22-23 gill rakers on lower arm of first gill arch; body scaleless; pectoral spine strong and serrated; adipose fin shorter than head and shorter or as long as anal fin base, distance between its origin and dorsal-fin base equal to or longer than adipose fin length; head more or less conical; nasal barbels reaching well behind eyes; maxillary barbels reaching to or beyond anal fin base; body and fins uniformly dark grey.

Mystus vittatus (Bloch, 1794) (striped dwarf catfish)

Distribution: Fresh- and brackish waters; AsiaIndian subcontinent, including Pakistan, India, Sri Lanka, Nepal, Bangladesh, and probably Myanmar; reported from Malaysia, Laos, Bhutan, Vietnam, and Cambodia (Smith 1945, Kottelat 1985); Phu Quoc: Duong Dong River drainage (purchased on the market).

Specimens: $n=4 ; 107-132 \mathrm{~mm}$ TL.

Diagnosis: $D$ II 7; $A$ III 8-9; second dorsal spine finely serrated on its inner edge; nasal barbels extending to opercular bone; maxillary barbels extending to end of anal fin; adipose fin small, inserted much behind rayed dorsal fin but anterior to anal fin; colour reddish-brown with silvery tint; three dark grey longitudinal stripe on side; narrow dusky spot on shoulder.

\section{ORDER MUGILIFORMES (mullets)}

FAMILY MUGILIDAE (mullets)

Crenimugil crenilabis (Forsskål, 1775) (fringelip mullet)

Distribution: Marine- and brackish waters; IndoPacific_-Red Sea and East Africa to the Line- and Tuamotu islands, north to southern Japan, south to Lord Howe Island (Harrison and Senou 1999); Phu Quoc: river mouths both in the northern and southern parts of the island (\# 1, 37, 44).

Specimens: $n=10 ; 25-78 \mathrm{~mm}$ TL.

Diagnosis: Head moderately flattened and convex between eyes; upper lip very thick, its depth less than 10 times in head length; lower part of upper lip with papillae; preorbital slightly notched; lower lip with fine crenate fringe on inner part; caudal fin forked.

\section{Liza vaigiensis (Quoy et Gaimard, 1825) (squaretail mullet)}

Distribution: Marine-, fresh-, and brackish waters; IndoPacific - Red Sea and East Africa to the Tuamotu Islands, north to southern Japan, south to southern Great Barrier Reef and New Caledonia (Harrison and Senou 1999); Phu Quoc: mouth area of the small river in the northern part of the island (\# 35).

Specimens: $n=3$; 26-36 mm TL.

Diagnosis: $A$ III 8; caudal fin semirectangular, its posterior margin nearly straight; dorsal fins and upper parts of pectoral fins black; caudal, anal, and pelvic fins distinctly yellow; lower parts of pelvic fins yellowish. 
Mugil cephalus Linnaeus, 1758 (flathead grey mullet)

Distribution: Marine-, fresh-, and brackish waters; cosmopolitan in coastal waters of the tropical, subtropical and temperate zones of all seas (Harrison and Senou 1999); Phu Quoc: lower part of the Ca River (\# 7).

Specimens: $n=1 ; 140 \mathrm{~mm}$ TL.

Diagnosis: $D$ V 7; $A$ III 8; lips thin; well developed adipose eyelid; pectoral fins short (do not reaching eye when folded forward); olive-green dorsally; sides silvery shading to white ventrally; lateral brown stripes distinctive.

Valamugil cunnesius (Valenciennes, 1836) (longarm mullet)

Distribution: Marine-, fresh-, and brackish waters; Indo-West Pacific south to South Africa (Harrison and Senou 1999); Phu Quoc: lower part of the Ca River (\# 7). Specimens: $n=1 ; 120 \mathrm{~mm}$ TL.

Diagnosis: $D$ IV 8; $A$ III 9; 37 pored scales in lateral line; pectoral fins $95 \%$ head length, reaching below origin of first dorsal fin; axillary scale nearly half length of pectoral fin; colour brownish- grey dorsally; sides silvery.

\section{ORDER ATHERINIFORMES (silversides)}

FAMILY PHALLOSTETHIDAE (tusked silversides and priapiumfishes)

Phenacostethus smithi Myers, 1928 (Smith's priapium fish)

Distribution: Fresh- and brackish waters; Asia-Chao Phraya basin (Thailand) and coastal streams of south-east Thailand and Cambodia, and Mekong basin; reported from Sumatra, Indonesia and Malaysia (Rainboth 1996, Kottelat 1989); Phu Quoc: Cua Can River drainage (\# 26).

Specimens: $n=8 ; 19-23 \mathrm{~mm}$ TL.

Diagnosis: $D_{1}$ I; $D_{2} 61 / 2 ; A$ II 13 ; ventral fins absent; male possess complicated fleshy appendage (priapium) suspended from head and shoulder girdle.

FAMILY ATHERINIDAE (old world silversides)

Atherinomorus duodecimalis (Valenciennes, 1835) (tropical silverside)

Distribution: Marine- and brackish waters; Indo-West Pacific (Ivantsoff and Crowley 1999); Phu Quoc: lower part of the Ca River (\# 7).

Specimens: $n=8 ; 40-61 \mathrm{~mm}$ TL.

Diagnosis: 33-38 midlateral scales; $17-19$ predorsal scales; 11 or more anal-fin soft rays; more than 21 gill rakers on lower part of first gill arch; preopercle with notch on anterior edge; ascending process of premaxilla short and broad, its lateral process broad and flat; anus in front of pelvic fin tip; origin of second dorsal fin usually behind tips of pelvic fins.

ORDER BELONIFORMES (needlefishes)

FAMILY ADRIANICHTHYIDAE (adrianichthyids) Oryzias javanicus (Bleeker, 1854) (Javanese ricefish)

Distribution: Fresh- and brackish waters; AsiaIndonesia, Singapore, Malaysia, Thailand; recorded from the Mekong River (Parenti 2008); Phu Quoc: several sites with brackish water in different parts of the island (\# 1, 36, 37-39, 46).
Specimens: $n=32 ; 24-31 \mathrm{~mm}$ TL.

Diagnosis: $D$ 6-7; $A$ 18-22; V 5-6; P 10-11; C I 4/5 I, 26-29 scales in lateral line (meristic characters were calculated for few specimens); moderately deep-bodied: greatest depth no more than 30\% SL; anal fin subtriangular, anteriormost fin ray short, followed by several elongate rays decreasing in length posteriorly; no discrete black blotch on dorsal half of pectoral-fin base; caudal fin truncate with medial rays some elongate; bilobed and enlarged urogenital papillae of female; yellow dorsal and ventral caudal-fin margins.

\section{FAMILY HEMIRAMPHIDAE (halfbeaks)}

Dermogenys pusilla Kuhl et van Hasselt, 1823 (wrestling halfbeak)

Distribution: Marine-, fresh-, and brackish waters; Asia-Thailand to Indonesia, including India, Myanmar, and Bangladesh (Rainboth 1996); Phu Quoc: the majority of the studied sites in different parts of the island with both fresh (\# 2-6, 8, 9, 14, 26, 31, 34, 43) and brackish waters $(1,36,37,39,41,42)$.

Specimens: $n=8$; 40-61 mm TL.

Diagnosis: $D$ 9-11 (first 3-4 unbranched); $A$ 13-15 (first 8-9 unbranched); $P$ I 7-9; lower jaw extended; caudal fin rounded; first anal-fin rays modified in males (the first one is short and hard, second one has upper end curved down (spoon like) and bearing short lateral branch, third- and fourth ray having their upper parts curved down, and four next rays are shortened, noticeably different from next normal branched rays); dorsal-fin origin behind anal-fin origin; dorsal-fin base shorter than anal-fin base; anterior parts of both dorsal and anal fins and anterior end of lower jaw usually with orange or yellow stripes (mostly in males); prominent black spot at posterior part of dorsal fin in males.

Zenarchopterus dunckeri Mohr, 1926 (Duncker's river garfish)

Distribution: Brackish water; Indo-West PacificAndaman Islands, New Guinea, the East Indies and the Admiralty, Solomon, and the Ryukyu Islands; reported from the estuaries along the Cambodian coast (Collette and $\mathrm{Su}$ 1986); Phu Quoc: lower parts of some rivers in the northern and southern parts of the island (\# 22, 29, 37, 38).

Specimens: $n=6$; 66-140 mm TL.

Diagnosis: $D$ 101/2-11; $A$ I 8-10; fifth segmented analfin ray thickened and greatly elongate, reaching past base of caudal fin in mature males; fourth dorsal-fin ray of males thickened and much longer than other dorsal rays, its distal end flat and wider than other dorsal rays. ORDER CYPRINODONTIFORMES (killifishes) FAMILY APLOCHEILIDAE (Asian rivulines) Aplocheilus panchax (Hamilton, 1822) (blue panchax)

Distribution: Fresh- and brackish waters; AsiaPakistan, India, Bangladesh, Myanmar, and the IndoMalaysian archipelago; reported from Nepal, Cambodia, Vietnam, and Sri Lanka (Rainboth 1996, Vidthayanon et al. 1997, Vidthayanon 2008); Phu Quoc: fresh and brack- 
ish waters in different parts of the island (\# 1-3, 7, 8, 19, 23, 25-28, 31, 34, 36, 39, 41-44).

Specimens: $n=7 ; 32-74 \mathrm{~mm}$ TL.

Diagnosis: upper jaw protractile; pectoral-fin base entirely below mid-lateral axis of body; body coloured; dark blotch at dorsal-fin base; anal fin with red or orange margin.

\section{ORDER SYNBRANCHIFORMES (swamp eels) \\ FAMILY SYNBRANCHIDAE (swamp eels) \\ Monopterus albus (Zuiew, 1793) (Asian swamp eel)}

Distribution: Fresh- and brackish waters; Asia-India to China, Japan, Malaysia, and Indonesia (Kottelat 2001); Phu Quoc: Cua Can River drainage (collected by local fishermen and by us at site \# 31), Bai Dai River (\# 2).

Specimens: $n=10 ; 124-426 \mathrm{~mm}$ TL.

Diagnosis: Eel-form body; no scales; no pectoral- and pelvic fins; dorsal-, caudal-, and anal fins confluent and reduced to skin fold; gill openings merged into single slit underneath head; large mouth; eye small; body red to brown with sprinkling of dark flecks across back.

\section{FAMILY CHAUDHURIIDAE (earthworm eels)}

Chaudhuria caudata Annandale, 1918 (Burmese spineless eel)

Distribution: Freshwater; Asia-Myanmar to Cambodia (Kottelat 2001); Phu Quoc: a few rivers in the northern and central parts of the island (\# 6, 26, 30).

Specimens: $n=8 ; 30-42 \mathrm{~mm}$ TL.

Diagnosis: Eel-form body; no scales; caudal fin present, not fused with dorsal and anal fins; body brownish.

\section{FAMILY MASTACEMBELIDAE (spiny eels)}

Macrognathus circumcinctus (Hora, 1924)

Distribution: Freshwater; Asia-Mekong and Chao Phraya basins, southeastern Thailand, Malay Peninsula and Sumatra, Indonesia (Kottelat 2001); Phu Quoc: the majority of the studied freshwater sites in the northern and central parts of the island (\# 2, 4-6, 9, 11, 13, 15, 17, 20, 26, 30).

Specimens: $n=27$; 49-160 mm TL.

Diagnosis: $D$ XXVII-XXVIII 47-52; rim of anterior nostril with 6 fingerlike fimbriae; dorsal and anal fins confluent with caudal fin; series of very regular, oblique, dark bars, each with narrow extension extending partially or entirely across abdomen.

\section{Macrognathus siamensis (Günther, 1861) (peacock eel)}

Distribution: Freshwater; Asia-Mekong, Chao Phraya, Maeklong, Peninsular and Southeast Thailand river systems (Vidthayanon et al. 1997, Kottelat 1998); Phu Quoc: Duong Dong River basin (purchased on the market).

Specimens: $n=3$; 155-206 mm TL.

Diagnosis: $D$ XVI 56; dorsal, caudal and anal fins not fused; series of 2-4 conspicuous ocelli along base of soft dorsal fin; usually additional ocellus on base of caudal fin.

\section{Mastacembelus favus Hora, 1924 (tire track eel)}

Distribution: Freshwater; Asia-Thailand to the Malay Peninsula (Rainboth 1996); recorded from
Vietnam (Vidthayanon, 2008); Phu Quoc: Duong Dong River basin (purchased on the market).

Specimens: $n=2 ; 194-204 \mathrm{~mm}$ TL.

Diagnosis: $D$ XXXII-XXXIII 83-85; dorsal and anal fins confluent with caudal fin; whole body with reticulated pattern of dark markings that completely encircle belly.

\section{ORDER PERCIFORMES (perches)}

FAMILY AMBASSIDAE (Asiatic glassfishes)

Ambassis gymnocephalus (Lacepède, 1802) (bald glassy)

Distribution: Marine-, fresh-, and brackish waters; Indo-West Pacific (Allen 1999); Phu Quoc: lower parts of lowland rivers in different parts of the island, in brackish water (\# 1, 7, 39, 42).

Specimens: $n=5$; 30-40 mm TL.

Diagnosis: 3 supraorbital spines; 9 soft anal-fin rays; 13-15 predorsal scales; eye large, $13.0 \%-13.9 \%$ SL; nasal spine well developed; lateral line interrupted; hind margin of preopercle smooth.

Ambassis interrupta Bleeker, 1853 (long-spined glass perchlet)

Distribution: Marine-, fresh-, and brackish waters; Asia-Indo-Australian Archipelago to northern Australia and the Andaman Sea; reported from Palau and the Ryukyu Islands (Masuda et al. 1984, Allen 1999); Phu Quoc: the majority of the studied sites with brackish water all over the island (\# 1, 7, 18, 25, 28, 38, 39, 41, 42, 45).

Specimens: $n=22 ; 28-88 \mathrm{~mm}$ TL.

Diagnosis: Usually single supraorbital spine (one studied specimen from Dam River had second spine poorly developed); lateral line interrupted in middle portion, with 12-17 pored scales; second spine of first dorsal fin strong and very long, its height comprising 29.2\%-58.5\% SL (lower values observed in larger fishes); body depth $38.3 \%-61.0 \%$ SL (larger values observed in juveniles); interopercle margin with 4-8 small serrae (1-3 serrae in juveniles); nasal spine well developed; cheek with two scale rows; hind margin of preopercle smooth.

\section{Ambassis kopsii Bleeker, 1858 (freckled hawkfish)}

Distribution: Marine-, fresh-, and brackish waters; Indo-Pacific (Allen 1999); Phu Quoc: lower parts of several small rivers both in the northern and southern parts of the island (\# 18, 19, 22, 29, 35-39).

Specimens: $n=16$; 25-59 mm TL.

Diagnosis: Single supraorbital spine; 15 pectoral-fin rays; body depth $44.1 \%-44.4 \%$ SL; 9 predorsal scales; nasal spine not visible; cheek with two scale rows; lateral line complete, continuous to caudal fin base; both hind margin of preopercle and lower margin of interopercle smooth; second dorsal-fin spine longer than third spine; distinct black spot on upper part of spiny dorsal fin.

Ambassis macracanthus Bleeker, 1849 (estuarine glass perchlet) Distribution: Marine-, fresh-, and brackish waters.

Asia and Oceania (Allen 1999); Phu Quoc: lower parts of Dam and Duong Dong rivers (\# 39, 45).

Specimens: $n=8 ; 58-82 \mathrm{~mm}$ TL. 
Diagnosis: $D$ VIII 91/2; $A$ III 91/2; 13-14 pectoral-fin rays; lateral line complete, continuous to caudal fin base, with 29-32 pored scales; body depth $36.5 \%-40.7 \%$ SL; 17-22 predorsal scales; single supraorbital spine; nasal spine present, hidden under skin; cheek with two or more scale rows (lost in majority of studied specimens); both hind margin of preopercle and lower margin of interopercle smooth.

Ambassis vachellii Richardson, 1846 (Vachelli's glass perchlet)

Distribution: Marine-, fresh-, and brackish waters; Indo-West Pacific (Allen 1999); Phu Quoc: the majority of the sites with brackish water (\# 1, 7, 18, 19, 22, 25, 35, 38).

Specimens: $n=40$; 32-54 mm TL.

Diagnosis: 3 supraorbital spines; hind margin of preopercle with 6-13 small serrae; nasal spine well developed.

FAMILY SILLAGINIDAE (sillagos)

Sillago sihama (Forsskål, 1775) (silver sillago)

Distribution: Marine- and brackish waters; Indo-West Pacific; Mediterranean Sea (McKay 1999); Phu Quoc: mouth area of small rivers in the northern part of the island (\# 18, 29, 35).

Specimens: $n=2 ; 59-72 \mathrm{~mm} \mathrm{TL}$.

Diagnosis: $D_{1}$ XI; $D_{2}$ I 201/2-211/2; $A$ II 20-22; snout long and conical; swim bladder with two anterior and two posterior extensions; body uniform in coloration.

\section{FAMILY LUTJANIDAE (snappers)}

Lutjanus argentimaculatus (Forsskål, 1775) (mangrove red snapper)

Distribution: Marine-, fresh-, and brackish waters. Indo-West Pacific; has dispersed into the eastern Mediterranean (Anderson and Allen 2001); Phu Quoc: mouth area of some small rivers in the northern and central parts of the island (\# 25, 37, 45).

Specimens: $n=5 ; 22-38.5 \mathrm{~mm}$ TL.

Diagnosis: $D$ X 13-141/2; $A$ III 8; preopercle serrated; scales on check and opercle, but no scales between eye and mouth; vomer with teeth; scale rows on back more or less parallel to lateral line; back and sides brownish with 6-8 lighter bars (white in alcohol) crossing sides; two blue lines across cheek; dorsal, pelvic and anal fins red with more or less developed black ridge (only juveniles were studied).

Lutjanus russellii (Bleeker, 1849) (Russell's snapper)

Distribution: Marine- and brackish waters; Indo-West Pacific (Anderson and Allen 2001); Phu Quoc: the majority of the studied sites with brackish water all over the island (\# 1, 19, 25, 29, 37-39, 44, 45).

Specimens: $n=7 ; 29-108 \mathrm{~mm}$ TL.

Diagnosis: $D$ X 14-141/2; $A$ III 8-81/2; dorsal profile of head steeply to moderately sloped; preopercular notch and knob poorly developed; scale rows on back rising obliquely above lateral line; vomerine tooth patch triangular with medial posterior extension; black spot on lateral line below anterior portions of soft dorsal fin; juveniles yellowish with four brown stripes on sides.
Lutjanus johnii (Bloch, 1792) (John’s snapper)

Distribution: Marine- and brackish waters; Indo-West Pacific (Anderson and Allen 2001); Phu Quoc: lower parts of Duong Dong and Dam rivers (\# 39, 45).

Specimens: $n=3$; 56-85 mm TL.

Diagnosis: $D$ X $14 \frac{1}{2}$; $A$ III $81 \frac{1}{2}$; preorbital width 6.2 times in head length; scale rows on back parallel to lateral line; vomerine tooth patch triangular, without medial posterior extension; body yellow; central portion of each scale with reddish-brown spot, giving overall appearance of series of horizontal lines on body side; large black blotch mainly above lateral line below anterior dorsal-fin rays.

FAMILY GERREIDAE (mojarras)

Gerres filamentosus Cuvier, 1829 (whipfin silver-biddy)

Distribution: Marine-, fresh-, and brackish waters; Indo-Pacific (Woodland 2001a); Phu Quoc: lower parts of Duong Dong and Ca rivers $(\# 7,45)$.

Specimens: $n=1 ; 103 \mathrm{~mm}$ TL.

Diagnosis: $D$ IX $10 \frac{1}{2} ; A$ III $8 ; 5$ scale rows between lateral line and base of fifth dorsal-fin spine; second dorsal-fin spine laterally compressed and elongate (tip broken); silvery body with vertical series of spots along side.

Gerres longirostris (Lacepède, 1801) (strongspine silverbiddy)

Distribution: Marine-, fresh-, and brackish waters; Indo-Pacific (Woodland 2001a); Phu Quoc: the majority of the studied sites with brackish water all over the island (\# 1, 18, 29, 35, 38, 39, 45, 46).

Specimens: $n=23 ; 37-83 \mathrm{~mm}$ TL.

Diagnosis: D IX 10; body depth 2.1 to 2.3 times in SL; scales in interorbital area not extending on broad front down to nostrils, but extending as pair of horns, leaving skin over premaxillary groove scaleless; second dorsal-fin spine not greatly elongate, not reaching insertion of first anal-fin spine when depressed; second anal-fin spine robust and long, its length subequal with length of analfin base or some shorter; depressed pectoral fins just reaching origin of first anal-fin spine; second dorsal-fin spine shorter than head length without snout; small specimens with dusky bars across body side.

FAMILY HAEMULIDAE (grunts)

Plectorhinchus gibbosus (Lacepède, 1802) (Harry hotlips)

Distribution: Marine-, fresh-, and brackish waters; Indo-West Pacific (McKay 2001); Phu Quoc: mouth area of small river (\# 44).

Specimens: $n=1 ; 51 \mathrm{~mm}$ TL.

Diagnosis: $D$ XIV 16; $A$ III 7; chin with 6 pores, without barbels or papillae; space between eye and mouth scaled; margin of preopercle serrated; body and dorsal fin uniform brownish.

\section{FAMILY TOXOTIDAE (archerfishes)}

Toxotes jaculatrix (Pallas, 1767) (banded archerfish)

Distribution: Fresh- and brackish waters; Asia and 
Oceania-India eastward to the Philippines, and south to Indonesia, Vanuatu, Solomon Islands, Papua New Guinea, and northern Australia (Allen 1991); Phu Quoc: Duong Dong River (\# 45).

Specimens: $n=1 ; 104 \mathrm{~mm}$ TL.

Diagnosis: $D$ IV 11; $A$ III 16; 29 pored scales in lateral line; head and body with 6 vertical black bars extending to longitudinal axis, including narrow one through eye and another one at caudal fin base.

\section{FAMILY NANDIDAE (Asian leaffishes)}

Nandus nebulosus (Gray, 1835) (Bornean leaffish)

Distribution: Fresh- and brackish waters; Asia-areas around the Gulf of Thailand (our unpublished data); Phu Quoc: the majority of the studied sites with fresh water in the northern and central parts of the island (\# 2, 4-6, 9; 12-14, $16,17,20,23,26,27,30$ ), was not found in brackish waters.

Specimens: $n=6 ; 74-86 \mathrm{~mm}$ TL.

Diagnosis: $D$ XIV-XV 111/2-12; $A$ III 51/2; $P$ 16; lateral line with $22-26$ pored scales in its upper part and 5-8 scales in lower part; 4 scales above lateral line and 11-12 scales below it; slender body, its depth $35.6 \%-40.0 \%$ SL; short snout, $22.2 \%-25.6 \%$ head length; head and body dark brown; no dark spot at caudal fin base and obvious dark stripes on head.

\section{FAMILY TERAPONIDAE (grunters)}

Terapon jarbua (Forsskål, 1775) (jarbua terapon)

Distribution: Marine-, fresh-, and brackish waters; Indo-Pacific (Vari 2001); Phu Quoc: mouth areas of different rivers all over the island (\# 18, 29, 35, 37, 41, 44, 45).

Specimens: $n=4 ; 31-121 \mathrm{~mm}$ TL.

Diagnosis: $D$ XI-XII 9-11, $A$ III 7-10; lower opercular spine extending well beyond opercular flap; post temporal bone exposed posteriorly and serrate; three or four curved dark brown bands from nape to hind part of body, lowermost continuing across middle of caudal fin.

\section{FAMILY CICHLIDAE (cichlids)}

Oreochromis niloticus (Linnaeus, 1758) (Nile tilapia)

Distribution: Fresh- and brackish waters; Africa, widely introduced for aquaculture also elsewhere (Kottelat 2001); Phu Quoc: Dam River and lower part of Duong Dong River (\# 39, 46).

Specimens: $n=3$; 45-79 mm TL.

Diagnosis: $D$ XV-XVIII 11-13; A III 9-11; single nostril on each side of snout; lateral line divided into two parts: anterior one curved, parallel to dorsal profile, posterior one straight on middle line of body; caudal fin with numerous vertical black stripes.

FAMILY LABRIDAE (wrasses)

Halichoeres vrolikii (Bleeker, 1855) (Indian Ocean pinstriped wrasse)

Distribution: Marine; Indo-West Pacific_-Maldives to Moluccas (Indonesia), northwards to the Andaman Sea (Westneat 2001); Phu Quoc: Duong Dong River (\# 45). Specimens: $n=1 ; 110 \mathrm{~mm}$ TL.
Diagnosis: $D$ IX $12 \frac{1}{2} ; A$ III $12^{1 / 2}$; lateral line continuous but steeply descending below dorsal fin, with 28 pored scales; 3 scale rows between lateral line and dorsal fin origin; check below eye without scales; anterior teeth in both jaws enlarged; body yellow-green with brown reticulate pattern on sides; dorsal-, anal-, and caudal fin yellow, with red reticulation; black spot at base of pectoral fin; head yellow-greenish, with broad rose and blue stripes.

FAMILY ELEOTRIDAE (sleepers)

Butis butis (Hamilton, 1822) (duckbill sleeper)

Distribution: Marine-, fresh-, and brackish water; Indo-West Pacific (Koumans 1953); Phu Quoc: several sites with brackish water in different parts of the island (\# 19, 25, 38, 45).

Specimens: $n=7 ; 58-125 \mathrm{~mm}$ TL.

Diagnosis: Separate pelvic fins; no teeth on vomer; preopercle without spine; bony crests in interorbital space well developed; lower jaw prominent; interorbital space, cheeks, and snout scaled; depth of caudal peduncle 2 or more than 2 times in its length; ctenoid scales between eye and orbital crest.

\section{Butis gymnopomus (Bleeker, 1853)}

Distribution: Fresh- and brackish waters; Asia-India, Singapore, Banka, Sumatra, Simalur, Nias, Java, Bali, Borneo, Celebes, Kabaena, New Guinea, Philippines, and the Solomon Islands (Koumans 1953); Phu Quoc: both fresh and brackish water sites in different parts of the island (\# 1, 7, 8, 38, 39, 41, 42, 45).

Specimens: $n=27 ; 25-105 \mathrm{~mm}$ TL.

Diagnosis: 14-17 predorsal scales; separate pelvic fins; no teeth on vomer; preopercle without spine; bony crests in interorbital space well developed; lower jaw prominent; interorbital space, cheeks, and snout naked; teeth of outer row enlarged; maxillary extends to below anterior part of eye; no axillary scales.

\section{FAMILY GOBIIDAE (gobies)}

Acentrogobius bontii (Bleeker, 1849)

Distribution: Marine- and brackish waters; Indo-West Pacific (Koumans 1953); Phu Quoc: brackish waters in the northern and central parts of the island (\# 37, 45).

Specimens: $n=2$ females; $35.5-36 \mathrm{~mm}$ TL.

Diagnosis: $D_{1}$ VI; $D_{2}$ I $10-10 \frac{1}{2} ; A$ I $8 \frac{1}{2} ; 32-38$ scales in lateral series; $18-20$ predorsal scales; interorbital narrow, smaller than $1 / 2$ eye; single anterior interorbital pore present, followed by one pair of nasal pores near posterior nostrils; mouth oblique, lower jaw prominent; maxillary extends in front of middle of eye; two curved canines on each side in lower jaw; cheek and opercle naked; head naked above behind eyes (with obvious naked rhombic area), small cycloid scales beginning from about above opercle; body scales ctenoid; body reddish-brown, with indistinct darker blotches and light silvery small spots forming several rows below middle line of side in larger specimen; all fins with small dark spots; anal fin with dark margin and narrow stripe of small black spots in middle in larger specimen. 
Acentrogobius janthinopterus (Bleeker, 1853) (robust mangrove goby)

Distribution: Marine-, fresh-, and brackish waters; Eastern Indian Ocean and Western Pacific (Larson and Murdy 2001); Phu Quoc: Duong Dong River (purchased on the market).

Specimens: $n=5 ; 80-97 \mathrm{~mm}$ TL.

Diagnosis: $D_{1}$ VI; $D_{2}$ I $10 \frac{1}{2} ; A$ I $8 \frac{1}{2} ; 32-36$ scales in lateral series; $17-21$ predorsal scales; cheeks and opercle scaled on upper half with cycloid scales; several longitudinal rows of papillae on checks; body elongate, its depth 4-5 times in SL; foremost (except first) or middle dorsalfin spines are longest, elongate into filaments; caudal fin obtusely rounded, short, shorter than head; body brownish, lighter below; head mostly with 2-3 dark stripes from snout to eye; dark strip from eye to opercle, and another one from maxillary to opercle; numerous irregular dark spots on sides, arranged to longitudinal row in middle of side; lateral scales with many shiny spots; dorsal and caudal fins with small black spots; caudal fin in adult males with dark line of spots parallel to its edge, followed by parallel light yellow border; two longitudinal dark strips on base of pectoral fin.

\section{Brachygobius doriae (Günther, 1868)}

Distribution: Fresh- and brackish waters; AsiaIndonesia, Malaysia, Brunei, and Singapore (Larson 2001); Phu Quoc: Duong Dong River (\# 45).

Specimens: $n=10 ; 22-36 \mathrm{~mm}$ TL.

Diagnosis: $D_{1}$ VI; $D_{2}$ I $7-71 \frac{1}{2} ; A$ I $71 \frac{1}{2}-8 ; P$ 15-16; 25-27 scales in lateral series; check naked; opercle with large ctenoid scales; predorsal scales usually absent $(80 \%)$ (two specimens with 4 or 10 predorsal scales were found); teeth in upper jaw in several rows; tongue rounded; body anteriorly cylindrical, posteriorly compressed; live specimens orange or bright yellow with three wide black transversal bands: first from about head end to end of first dorsal fin, second band situated opposite to analand second dorsal fins, and third band-before caudal fin base; all bands reaching midventral line; transversal black band on head behind eye; usually narrow transversal band (or black spot) between first and second dorsal fin bases; lower parts of unpaired fins black, as well as anterior part of pectoral fin.

Drombus globiceps (Hora, 1923) (kranji drombus)

Distribution: Marine-, fresh-, and brackish waters; Asia and Oceania (Larson and Murdy 2001); Phu Quoc: a few studied sites with brackish or fresh water in the northern and southern parts of the island (\#1, 28, 34, 39).

Specimens: $n=4 ; 26-35 \mathrm{~mm}$ TL.

Diagnosis: $D_{1}$ VI; $D_{2}$ I $10^{1 / 2}-11 ; A$ I $8^{1 / 2}-9 ; P$ 16-17; 26-27 scales in lateral series; 7 predorsal scales; cheek, opercle, and anterior part of nape immediately behind eyes naked; single open pore in interorbital; both transversal and longitudinal rows of papillae on checks; body elongate, compressed, body depth 5.2-5.5 times in SL; caudal fin more or less pointed, longer than head; live specimens yellowish with irregular small red spots on upper sides and line of 4 elongate blackish spots in middle of side; few small, round, pearl-like, very shiny, blue dots, mainly in anterior part of body; fins red-greyish with minute dark spots; first dorsal fin with blackish spot behind fifth ray; anal fin with light margin after transversal dark stripe; an oblique light yellow band on upper half of caudal fin and three small dark spots on upper caudal margin.

\section{Exyrias puntang (Bleeker, 1851) (puntang goby)}

Distribution: Marine- and brackish waters; Western Pacific (Larson and Murdy 2001); Phu Quoc: brackish waters of the central part of the island $(\# 25,45)$.

Specimens: $n=11 ; 74-124 \mathrm{~mm}$ TL.

Diagnosis: $D_{1}$ VI; $D_{2}$ I $10^{1 / 2}$; $A$ I 91/2; 28-30 scales in lateral series; (9)10-11 predorsal scales; cheeks and opercle fully scaled, scales ctenoid; two longitudinal rows of papillae on checks; body deep, body depth less than 4 times in SL; foremost dorsal-fin spines longest, second and third rays usually elongated into filaments; caudal fin longer than head, obtusely rounded to pointed; body yellow-brownish, darker above; more than 6 diffuse transverse brown stripes on sides, more obvious before second dorsal fin; lateral scales with many shiny spots (still visible in fishes after ethanol fixation); dorsal fins with small black and yellow spots; caudal fin with black, yellow and reddish small spots; dark stripe (or blotch) from eye to end of mouth.

\section{Glossogobius giuris (Hamilton, 1822) (tank goby)}

Distribution: Marine-, fresh-, and brackish waters; Africa to Oceania; the majority of the inland freshwater bodies over the Indian Ocean and western Pacific (Koumans 1953); Phu Quoc: Duong Dong River (purchased on the market).

Specimens: $n=1 ; 115 \mathrm{~mm}$ TL.

Diagnosis: $D_{1}$ VI; $D_{2}$ I 91/2; $A$ I $8 \frac{1}{2} ; 33$ scales in lateral series; 22 predorsal scales; cheeks naked; opercle scaled in upper part only; lower jaw prominent; tongue bilobate; gill openings continuing far anteriorly, isthmus narrow; several longitudinal rows of papillae on checks, short suborbital longitudinal row of papillae behind eye present; iris of eye without process in pupil; caudal fin shorter than head; second spine of first dorsal fin filiform; body brownish, with numerous dark spots forming middle row of irregular large blackish spots; fins dark; dorsal-, caudal-, and pectoral fin rays spotted with dark small spots; pectoral fin with dark spot at base.

\section{Mugilogobius chulae (Smith, 1932) (yellowstripe goby)}

Distribution: Marine-, fresh-, and brackish waters; Western Pacific (Larson and Murdy 2001); Phu Quoc: brackish water in the mouth area of the small river in the northern part of the island (\# 25).

Specimens: $n=1$ male; $36.5 \mathrm{~mm}$ TL.

Diagnosis: $D_{1}$ VI; $D_{2}$ I $7 \frac{1}{2} ; A$ I $7 \frac{1}{2} ; P 20 ; 31$ scales in lateral series; 14 predorsal scales; snout broadly rounded; interorbital space broad, larger than eye; head pores absent; papillae in interorbital space forming long, curved row around top of each eye; mouth oblique, 
reaching past middle of eye; opercle with small cycloid scales; cheeks naked; caudal fin rounded, shorter than head; second and third spines of first dorsal fin elongate; body yellowish with black transversal stripes; blackish wide bars extending forward and upward from base of each pectoral fin to back, connected to each other in thin stripe across back; black transverse band at base of caudal fin followed by two dark spots before beginning of caudal rays, placed in vertical line; first dorsal fin with small black spot on anterior base and wide oblique black transverse band in its middle part; second dorsal fin with line of black small spots.

Mugilogobius rambaiae (Smith, 1945) (queen of Siam goby)

Distribution: Marine-, fresh-, and brackish waters; Asia: Sri Lanka, Myanmar, Thailand, Malaysia, Singapore, Indonesia and Papua New Guinea (Larson 2001); Phu Quoc: the lower part of the Cai Lap River (\# 42).

Specimens: $n=3 ; 24-37 \mathrm{~mm}$ TL.

Diagnosis: $D_{1}$ VI; $D_{2}$ I 71/2-8; $A$ I $7 \frac{1}{2}-8 ; P$ 15-16; 32-38 scales in lateral series; $17-19$ predorsal scales; snout broadly rounded, ending in front of upper lip; interorbital space broad, larger than eye diameter; head pores absent; papillae in interorbital space forming long, curved row around top of each eye; opercle with small cycloid scales; cheek naked; caudal fin rounded, shorter than head; body greyish; back with several indistinct black bars; each scale of side and back with short curved dark lines; distinct blackish oblique shoulder bar present; black stripes on head forming reticular pattern; caudal fin with 6-9 dark curved wavy cross stripes.

\section{Psammogobius biocellatus (Valenciennes, 1837) (sleepy goby)}

Distribution: Marine-, fresh-, and brackish waters; Indo-Pacific and Western Central Pacific (Koumans 1953, Larson and Murdy 2001); Phu Quoc: the mouth area of a small river in the northern part of the island (\# 18).

Specimens: $n=8 ; 41-78 \mathrm{~mm}$ TL.

Diagnosis: $D_{1}$ VI; $D_{2}$ I 91/2; $A$ I $81 \frac{1}{2} ; 31-35$ scales in lateral series; $16-18$ predorsal scales; cheeks naked; opercle scaled in upper part only; lower jaw prominent; tongue bilobate; gill openings far continued anteriorly, isthmus narrow; several longitudinal rows of papillae on checks; head depressed; iris of eye with process in pupil; caudal fin shorter than head; body dark brown with irregular blackish spots; dorsal-, anal-, and caudal fins blackish with small light spots and light borders; first dorsal fin with two large black spots on upper anterior and lower posterior parts.

\section{Pseudogobius javanicus (Bleeker, 1856)}

Distribution: Marine-, fresh-, and brackish waters; Indo-West Pacific (Larson and Murdy 2001); Phu Quoc: the majority of the studied sites with brackish water all over the island (\# 1, 18, 25, 28, 35-39, 42, 45, 46).

Specimens: $n=91 ; 24-49 \mathrm{~mm}$ TL.

Diagnosis: $D_{1}$ VI; $D_{2}$ I $7 \frac{1}{2}-8 ; A$ I $7 \frac{1}{2}-8 \frac{1}{2} ; 27-28$ scales in lateral series; usually 7 predorsal scales; $15-16$ segmented caudal-fin rays; paired anterior interorbital pores present; pelvic frenum simple; mouth small, subterminal; rounded snout overhanging mouth; opercle scaled with large cycloid and ctenoid (on upper part of larger specimens) scales; cheek naked, with papillae in longitudinal pattern; interorbital space narrow, about $1 / 2$ eye diameter; body greenish, with numerous minute spots and dark stripes; often dark stripe obliquely forward from first dorsal fin; first dorsal fin with black blotch; caudal fin base with 2 black spots in vertical line; head with one dark stripe from eye to maxilla and another one from eye to lower preopercle edge; first two rays of first dorsal fin elongate in mature males.

\section{Pseudogobius poicilosoma (Bleeker, 1849)}

Distribution: Fresh- and brackish waters; Asia and Oceania (Larson 2001); Phu Quoc: several sites with fresh or brackish water in northern and central parts of island (\# 3, 8, 9, 26, 37).

Specimens: $n=26 ; 12.5-33 \mathrm{~mm}$ TL.

Diagnosis: $D_{1}$ VI; $D_{2}$ I 7-71/2; $A$ I 61/2-7; 24-25 scales in lateral series; 6-7 predorsal scales, first scale unpaired and some enlarged; body slightly compressed, body depth 4.5-5.2 times in SL; checks naked; opercle scaled with large cycloid scales; interorbital narrow, less than $1 / 2$ eye diameter; paired anterior interorbital pores present; no open pores on preopercle; mouth oblique, maxillary extending to middle of eye; caudal fin shorter than head; live specimens yellowish with reddish-brown reticulate pattern, forming indistinct blotches above middle of side, and more or less obvious alternating longitudinal row of elongate narrow spots along middle of body; two dark spots at caudal fin base usually more or less merged and also combined with elongate spot from middle of side, forming horizontally turned " $\gamma$ "; dorsal and caudal fins with irregular rows of small dark spots; usually wide dark band in middle part of first dorsal fin or dark blotch in its posterior part; dark spot in upper anterior part of pectoral fin.

\section{Redigobius bikolanus (Herre, 1927) (speckled goby)}

Distribution: Marine-, fresh-, and brackish waters; Asia and Oceania; reported from Africa and Seychelles (Larson 2001); Phu Quoc: Dam River (\# 39).

Specimens: $n=27$; $15-29 \mathrm{~mm}$ TL.

Diagnosis: $D_{1}$ VI; $D_{2}$ I $7 \frac{1}{2}\left(8 \frac{1}{2}\right) ; A$ I 51/2-61/2; 17 segmented caudal-fin rays; $22-24$ scales in lateral series; 7 predorsal scales, first scale unpaired and some enlarged; body oblong, usually strongly compressed, body depth 3.8-4.7 times in SL; checks naked; opercle scaled with large cycloid scales; interorbital narrow, less than $1 / 2$ eye diameter; paired anterior interorbital pores present; 3 large open pores on each preopercle; mouth terminal with maxillary extending to middle of eye in female and subinferior mouth with maxillary extending beyond posterior margin of eye in males; caudal fin shorter than head; live specimens reddish with irregular dark spots; obvious dark elongate vertical spot immediately before anal fin base followed by 4 black blotches on ventral median line; black blotch on posterior 
part of first dorsal fin; two black blotches on base of caudal fin; mature males and females becoming dark, blackish; first dorsal-fin rays in breeding males becoming filaments.

\section{Redigobius dispar (Peters, 1868)}

Distribution: Fresh- and brackish waters; AsiaPhilippines and Indonesia; Oceania; Micronesia (Larson and Murdy 2001); Phu Quoc: the mouth area of the small river in the Bai Thom region (\# 19).

Specimens: $n=1$ female; $25 \mathrm{~mm}$ TL.

Diagnosis: $D_{1}$ VI; $D_{2}$ I 71/2; $A$ I 7; 17 segmented caudal-fin rays; $27-28$ scales in lateral series; 8 predorsal scales, first scale unpaired and enlarged; body oblong, deep, body depth 3.5 times in SL; checks naked; opercle scaled with large cycloid scales; interorbital narrow, less than $1 / 2$ eye diameter; paired anterior interorbital pores present; 3 open pores on each preopercle; mouth terminal; caudal fin shorter than head; body yellowish; top of snout and interorbital dark brown; fins dusky with stripes of light spots; large black spot on posterior upper part of first dorsal fin; no dark spots at base of caudal fin.

FAMILY SIGANIDAE (rabbitfishes)

Siganus canaliculatus (Park, 1797) (white-spotted spinefoot)

Distribution: Marine- and brackish waters; Indo-West Pacific (Woodland (2001b); Phu Quoc: Duong Dong River (\# 45).

Specimens: $n=2 ; 72-108 \mathrm{~mm}$ TL.

Diagnosis: $D$ XIII 10; $A$ VII 9; midline of thorax in front of pelvic fins scaleless; caudal fin concave in juveniles; third dorsal-fin ray shorter than distance from anterior nostril to posterior extremity of orbit; pectoral fins about 1.3 times in head length; last anal-fin spine more than $1 / 2$ length of longest anal-fin spine; numerous light blue spots on nape and trunk, with smaller sizes above lateral line; dark spot behind opercle.

Siganus guttatus (Bloch, 1787) (goldlined spinefoot)

Distribution: Marine- and brackish waters; Eastern Indian Ocean and Western Pacific (Woodland (2001b); Phu Quoc: Duong Dong River (\# 45).

Specimens: $n=2 ; 86-88 \mathrm{~mm}$ TL.

Diagnosis: $D$ XIII 10; $A$ VII 9; midline of thorax in front of pelvic fins scaly; shortest distance between bony orbit and upper lip greater than $1 / 2$ diameter of bony orbit; large round yellow spot (as large as eye) below rear base of soft portion of dorsal fin; numerous bronze-gold spots over sides.

Siganus javus (Linnaeus, 1766) (streaked spinefoot)

Distribution: Marine- and brackish waters; IndoPacific (Woodland (2001b); Phu Quoc: the majority of the studied sites with brackish water all over the island (\# 19, 22, 25, 28, 29, 39, 41, 45).

Specimens: $n=9 ; 21-143 \mathrm{~mm}$ TL.

Diagnosis: midline of thorax in front of pelvic fins scaly; dorsal- and anal-fin spines stout; shortest distance between bony orbit and upper lip less than $1 / 2$ diameter of bony orbit.
Siganus spinus (Linnaeus, 1758) (little spinefoot)

Distribution: Marine. Indo-Pacific (Woodland 2001b); Phu Quoc: a few sites with brackish water in the northern and central parts of the island (\# 1, 22, 41).

Specimens: $n=8$; 26-45 mm TL.

Diagnosis: midline of thorax in front of pelvic fins scaleless; anal- and at least posterior dorsal-fin spines stout; caudal fin barely concave; third dorsal-fin ray longer than distance from anterior nostril to posterior extremity of orbit; head and body marked with blue labyrinthine lines on light grey; caudal peduncle distinctly barred; bands dark brown and whitish.

\section{FAMILY SPHYRAENIDAE (barracudas)}

Sphyraena pinguis Günther, 1874 (red barracuda)

Distribution: Marine. Northwest Pacific (Doiuchi and Nakabo 2005); Phu Quoc: Dam River (\# 39).

Specimens: $n=1 ; 51 \mathrm{~mm}$ TL.

Diagnosis: 84 pored lateral-line scales; 10 scales above lateral line; 12 scales below lateral line; posterior tip of opercle sharply pointing just above level of pectoral-fin base; single longitudinal dark grey stripe laterally, running from tip of snout through eye, above pectoral fin base.

FAMILY ANABANTIDAE (climbing gouramies)

Anabas testudineus (Bloch, 1792) (climbing perch)

Distribution: Fresh- and brackish waters; Asia-India to Wallace line including China (Kottelat 1998); Phu Quoc: fresh and brackish waters in different parts of the island (\# 1, 2, 17, 22, 39).

Specimens: $n=2 ; 105 \mathrm{~mm}$ TL.

Diagnosis: $D$ XVII 10; $A$ IX-X 9-11; head scaled, with 4-5 scale rows between eye and rear margin of preopercle; scales large and regularly arranged, ciliate; body dark to pale greenish, very pale below; back dusky to olive; head with longitudinal stripes ventrally; posterior margin of opercle with dark spot; iris golden reddish.

\section{FAMILY OSPHRONEMIDAE (gouramies)}

Belontia hasselti (Cuvier, 1831) (Malay combtail)

Distribution: Freshwater; Asia-Malay Peninsula, Greater Sunda Islands (Kottelat et al. 1993); Phu Quoc: two dead specimens were found in the left branch of Tram River (\# 16).

Specimens: $n=2$; (approximately) $130 \mathrm{~mm}$ TL.

Diagnosis: $D$ XV 11; $A$ XVI 12; P 12; ventral fin with a long filiform outer rays reaching to about 10th anal spine; caudal fin rounded; body brownish grey; dark spot at base of soft dorsal-fin rays; unpaired fins with numerous dark spots forming mosaic-type pattern.

\section{Betta prima Kottelat, 1994}

Distribution: Freshwater; Asia-southeastern Thailand and Mekong basin in Laos and Cambodia (Kottelat 2001); Phu Quoc: the majority of the studied freshwater sites all over the island (\# 1-6, 9, 11-17, 20, $23-24,26,27,30,31,43)$ and also brackish water in the lower part of the Ca River (\# 7).

Specimens: $n=44 ; 23-77 \mathrm{~mm}$ TL. 
Diagnosis: $D$ (0)I-II 7-9; $A$ (I)II(III) 21-25; head length 2.7-2.9 times in SL; anal fin extending about to mid-length of caudal fin in male; both sexes with brown body with 3 dark stripes; anal fin with dark margin and blue submarginal band in live adult male.

Trichopodus trichopterus (Pallas, 1770) (three spot gourami) Distribution: Freshwater; Asia-Mekong basin in Laos, Yunnan, Thailand, Cambodia, and Vietnam; Southeast Asia; introduced elsewhere (Rainboth 1996, Kottelat 1998); Phu Quoc: the majority of the studied freshwater sites all over the island (\# 1, 2, 6, 8, 9, 16, 17, 23, 26, 27,43 ) and also brackish water in the Dam River (\# 39).

Specimens: $n=20 ; 61-102 \mathrm{~mm}$ TL.

Diagnosis: $D$ VI-VII 8-9; $A$ XI 32-35; 35-40 pored scales in lateral line; mouth very small, very oblique; upper jaw vertical and somewhat protractile; lower jaw prominent; black spots in middle of side and at caudal-fin base.

\section{Trichopsis vittata (Cuvier, 1831) (croaking gourami)}

Distribution: Freshwater; Asia-Thailand to Vietnam and the islands of Sumatra, Borneo, and Java (Rainboth 1996, Kottelat 2001); distributed to many countries through the aquarium trade industry; Phu Quoc: the majority of the studied freshwater sites all over the island (\# 1-5, 9, 17, $23,24,26,27,30,31,43)$ and also brackish water in the Cai Lap River (\# 42).

Specimens: $n=25 ; 20-54 \mathrm{~mm}$ TL.

Diagnosis: $D$ (II) III-IV 7-8; $A$ VI-VII 25-27; 3-4 stripes along body; anal fin with few elongate, filamentlike rays extending backwards almost to tip of caudal fin; black blotch above pectoral-fin base.

\section{FAMILY CHANNIDAE (snakeheads)}

Channa lucius (Cuvier, 1831)

Distribution: Freshwater; Asia-Thailand to Indonesia (Rainboth 1996); Phu Quoc: some freshwater sites in the northern part of the island (\# 2, 17, 22) and Cua Can River drainage (specimens collected by local fishermen).

Specimens: $n=7$; 114-198 mm TL.

Diagnosis: $D$ 401/2-41; $A$ 28-281/2; lateral line usually continuous with $64-70$ pored scales; $11-13$ rows of scales between eye and corner of preopercle; vomer and palatine with large canine teeth; snout length shorter or about equal to interorbital width; series of large dark blotches on side and oblique bars on belly; dark stripe on head through eye to lower opercle edge; large dark spot on opercle; pectoral fins with dark transverse stripes.

Channa micropeltes (Cuvier, 1831) (Indonesian snakehead)

Distribution: Freshwater; Asia-Mekong and Chao Phraya basins; the Malay Peninsula, and the islands of Sumatra and Borneo (Roberts 1989); Phu Quoc: Duong Dong River (purchased on the market).

Specimens: $n=1 ; 408 \mathrm{~mm}$ TL.

Diagnosis: lateral line not interrupted with 88 pored scales; vomer and palatine with canine teeth; two black longitudinal stripes from eye to caudal fin base, with light orange intermediate area spotted by large black irregular blotches; back blackish; belly light orange; caudal and pectoral fins black with red lower edge; longitudinal black stripe on dorsal fin.

Channa orientalis Bloch et Schneider, 1801 (walking snakehead)

Distribution: Fresh- and brackish waters; AsiaAfghanistan and Baluchistan southward to Sri Lanka and eastward to Indonesia (Rainboth 1996); Phu Quoc: several freshwater sites in the northern and central parts of the island (\# 1, 5, 14, 26, 40).

Specimens: $n=8$; 40-166 mm TL.

Diagnosis: $D$ 32-36; $A$ 22-23; lateral line usually interrupted with 11-14 pored scales in upper anterior part and 30-33 pored scales in lower posterior (total scale number 42-46); 4-5 rows of scales between eye and corner of preopercle; snout length about 1.5 times in interorbital width; vomer and palatine with two series of mostly canine teeth; dark spot at pectoral-fin base followed by several equally spaced and distinct transverse orange and dark bars in pectoral fin; dorsal-, anal- and caudal fins with narrow red margin (turning white in alcohol).

\section{Channa striata (Bloch, 1793) (striped snakehead)}

Distribution: Fresh- and brackish waters; AsiaPakistan to Thailand and south China (Rainboth 1996); Phu Quoc: some freshwater sites in the northern and central parts of the island (\# 2, 22), Duong Dong and Cua Can River basins (collected by local fishermen).

Specimens: $n=9$; TL 100-190 mm TL.

Diagnosis: $D$ 41-431/2; $A$ 26-27; lateral line curved down (or interrupted) after 19th-21st pored scale, total number of pored scales 55-59; 6-7 rows of scales between eye and corner of preopercle; vomer and palatine with bands of small or some enlarged teeth, non canines; snout length shorter than interorbital width; side with oblique bars indistinct in upper part of body; no dark transversal stripes on pectoral fins.

ORDER TETRAODONTIFORMES (puffers and filefishes) FAMILY TETRAODONTIDAE (puffers)

Chelonodon patoca (Hamilton, 1822) (milkspotted puffer)

Distribution: Marine-, fresh-, and brackish waters; Indo-Pacific (Matsuura 2001); Phu Quoc: lower part of the Cai Lap River (\# 41).

Specimens: $n=2$; 19-26 mm TL.

Diagnosis: $D$ 9-10; $A$ 8-9; two lateral lines, upper joining lower above or behind anal fin; nasal organ with raised margin expanded before and behind into pair of elongate flaps.

Tetraodon nigroviridis Marion de Procé, 1822 (spotted green pufferfish)

Distribution: Fresh- and brackish waters; Asia-Sri Lanka to Indonesia and north to China (Matsuura 2001); Phu Quoc: Duong Dong River (\# 45). 
Specimens: $n=2 ; 76-85 \mathrm{~mm}$ TL

Diagnosis: $D$ 13-14; A 10-11; each nostril with bifid tentacle; upper head, back and sides with numerous large dark blotches surrounded by yellow borders; $4-6$ irregular narrow bars on caudal fin.

The majority of collected species are consistent in their main diagnostic characters with known valid taxa available in the scientific literature. But it should be mentioned that published data for some species is scant or even controversial, e.g., western Pacific gobiids, known to be difficult in identification and which prompted a more detailed study in this contribution. At the same time among cypriniform fish we revealed two species which were identified as members of genera Rasbora and Barbucca, respectively. Both of them demonstrate prominent differences in some morphological features and pigmentation comparing with their valid congeners which populate neighbouring mainland- or island waters. These species are designated as Rasbora sp. and Barbucca sp. in this paper and their diagnoses present mainly features corresponding to their generic state. Both species will be described as new taxa in a separate publication.

In addition to the aforementioned new species, our data on the number of anal-fin rays in studied specimens of Kryptopterus bicirrhis show significant differences between the island- and continental populations (Table 2). On the one hand, the observed differences may be related with size-age variability of character: we studied only young specimens 40-83 $\mathrm{mm}$ TL, whereas the largest specimens of this species reach $150 \mathrm{~mm}$ SL (Kottelat 2001). But it is more likely that observed differences reflect the real divergence between the island- and the mainland- populations. The studied specimens have the same numbers of anal-fin rays as K. piperatus $\mathrm{Ng}$, Wirjoatmodjo et Hadiaty, 2004 described from northern Sumatra. But the latter species has more gill rakers (16-17), smaller eyes (20.3\%-25.3\% head length), and deeper body $(22.3 \%-24.3 \% \mathrm{SL})(\mathrm{Ng}$ et al. 2004). We believe the problem of the taxonomic status of Kryptopterus specimens from the Phu Quoc Island needs further specialised studies. In this contribution we identified them as populations of $K$. bicirrhis.

More interesting results were obtained for the goby Brachygobius doriae. This species was collected at the only studied site: the lower part of the Duong Dong River in Duong Dong City (Table 1, \# 45). Eight of the 10 studied specimens were typically lacking scales on the nape and back before the dorsal fin origin, whereas other fish had 4 or 10 predorsal scales. It should be noted that the presence or absence of predorsal scales constitutes the main diagnostic characters in gobies. The appearance of relatively high number of scaled specimens among fishes with typically naked back may be due to several factors:

- The mutation process in water polluted by municipal sewage;

- Probable hybridization with congeneric aquarium species accidentally stocked into the natural waters;

- Microevolutionary processes in natural population under a disruptive selection.

The estimate of the role of these factors requires special studies, but in any case there is no reason to suggest the presence of a new species of genus Brachygobius on the Phu Quoc Island.

Only 33 species (34.4\%) on our list have been considered freshwater fishes, the majority are cypriniforms (15 species) or siluriforms (8 species), while the rest are synbranchiforms (4 species), osphronemids (4), and channids (2). It is of particular interest that families with freshwater origin, namely Cyprinidae, Cobitidae, and Balitoridae, being represented by high species diversity in neighbouring mainland faunas (see Kottelat 1989) do not have many representatives on the island: 12,3 , and 1 species, respectively. Moreover, six species usually treated as freshwater (Froese and Pauly 2012) were found in some brackish water habitats of the Phu Quoc Island. These species, Danio albolineatus, Puntius binotatus, Rasbora paviana, Betta prima, Trichopodus trichopterus, and Trichopsis vittata are widely distributed all over the island, whereas "true" freshwater species (Parachela maculicauda, Rasbora aurotaenia, Rasbora sp., Barbucca sp., Amblyceps mangois) had limited distribution, some of them being found in the Cua Can River drainage only. Besides, four of the six aforementioned widely distributed species occur in different freshwater habitats: from hill streams with stone bottoms (genera Danio, Puntius, Rasbora) or forest streams with sandy and stone bottoms (Betta prima) to lowland rivers with developed vegetation, muddy bottoms, and slow flow.

We can presume that the main trends in the history of the ichthyofauna of the Phu Quoc Island were the elimination of true freshwater stenobiontic species adapted to limited habitats and the progressive development of euryhaline and eurytropic species replacing former species as biotopes of relatively small tropical islands changed, e.g., as river systems became significantly reduced during the dry seasons. Indeed, at the beginning of the dry season, we collected fish from isolated residual pools of drying up river bed. Fishes of the same pool were presented by a few specimens of several different species. However,

Table 2

The number of anal-fin rays $(A)$ in Kryptopterus bicirrhis from the Phu Quoc Island compared with data from published sources

\begin{tabular}{llc}
\hline Source & Locality & $A$ \\
\hline Presently reported study & Phu Quoc Island & $49-54$ \\
Kottelat 2001 & Laos & $55-68$ \\
Smith 1945 & Cambodia & $52-70$ \\
\hline
\end{tabular}


we did not find true freshwater fishes among them. The most typical set of species included species dwelling both fresh and brackish waters: Monopterus albus, Nandus nebulosus, Anabas testudineus, and Channa striata. These species, particular Anabas testudineus (see Alam et al. 2006), demonstrating high adaptability, are characterized by wide areas and possess ability to withstand harsh environmental condition. The absence of true freshwater stenobiontic species constitute an evidence that aforementioned residual pools do not become a refuge for native freshwater faunas and do not constitute a starting point for further diversification of the survived, reduced populations (no founder effect). It means that many local freshwater populations disappear after the dry season and their habitats become populated by other species during the rains.

We believe that two of the 33 freshwater species recorded in the presently reported study evolved into separate new species confirmed by morphological study: Rasbora sp. and Barbucca sp. They comprise $6.1 \%$ of a total number of freshwater fishes and only $2.1 \%$ of a total number of native fish species revealed in the inland waters of the island. These species are not very similar in their ecological mobility, because Rasbora sp. occurs in all parts of the Phu Quoc Island and populates different kinds of freshwater habitats: hill streams, lowland rivers, lakes, and ponds. Whereas Barbucca sp. was found in the Cua Can River drainage only where it populated rivers or streams with sandy bottoms and rare patches of vegetation. However, both these species have one common feature-they are small short-lived fish. The largest studied specimen of Rasbora sp. reached only $37.3 \mathrm{~mm}$ TL, and the same of Barbucca sp.-34.2 mm TL. Thus, they should reach sexual maturity very early - at the age of several months. For example, Rasbora reticulata Weber et de Beaufort, 1915 with maximum length $60 \mathrm{~mm}$ TL matures at the age of 6-8 months and Rasbora sarawakensis Brittan, 1951 with $38 \mathrm{~mm} \mathrm{SL}$ - at the age of 8-12 months (Kočetov 1991). Different Rasbora species can live from 2 to 10 years in aquarium. Of course, under natural conditions small species are characterized by a shorter life span-usually not exceeding 4 years. And the possible number of generations within their lifetime (the maximum age divided by the minimum age of attaining sexual maturity) can be fewer than 4 . The same value should be expected for Barbucca sp. (The only known valid species of genus Barbucca-B. diabolica Roberts, 1989, is a poorly studied fish, not exceeding $24 \mathrm{~mm}$ SL.) Consequently, the complete change of generations of the aforementioned short-lived species might have occurred 2500 times during the presumed time of the isolation of the Phu Quoc ichthyofauna (about 10000 years). The above-mentioned estimated number of the generation changes is about two times higher than that for freshwater clariids. We use this group for comparison, since the only new fish species previously described from the Phu Quoc Island was Clarias gracilentus. There are no available data on its biology, but the oldest known specimens of the better studied Clarias gariepinus (Burchell, 1822) were 8 years old (Froese and Pauly 2012). The latter species reaches sexual maturity at the age of one year (Yalçin et al. 2001).

The complete change of generations in clariid fishes isolated in the Phu Quoc Island occurred fewer than 1250 times, and that was not enough for the new species divergence, since conspecific populations of Clarias gracilentus was also found in mainland southeastern Cambodia (Ng et al. 2011). Of course, we should not completely rule out the possibility of future discovery of mainland Cambodian populations conspecific with Rasbora sp. This miniature species may be overlooked in bodies of water of the mainland. The species Barbucca diabolica is recorded from Borneo (from Sarawak to the Mahakam drainages), from Sumatra (Batang Hari and most likely other drainages such as Musi), Malay Peninsula northwards to Sungaikolok (Thailand), southeastern Thailand, and Cambodia (western Tonle Sap basin) (Bignoli 2012). However, taxonomic relations of different populations were not specifically studied, and moreover, specimens from the Phu Quoc Island were also referred to the same species (Bignoli 2012). Thus, endemic state seems questionable in both revealed Rasbora sp. and Barbucca sp., however, they certainly had more possibilities for successive evolution than catfishes.

Moreover, we know that many fish taxa are characterized by a high evolutionary plasticity (cichlids, several cyprinodontids, cyprinids, etc.), whereas other fishes are more conservative. The genus Barbucca recently is treated as monotypic, but it is a balitorid fish characterized by high numbers of species and genera. For instance, 186 valid species were described in the genus Schistura (see Froese and Pauly 2012), 57 of them were found in Laos (Kottelat 2001), where they are often sympatric. Similarly, 93 valid species were described in the genus Rasbora (see Froese and Pauly 2012), 16 of them were found in Laos (Kottelat 2001). This data demonstrates both genera as fish groups with relatively high evolutionary mobility.

\section{CONCLUSIONS}

This investigation revealed that the inland ichthyofauna in the Phu Quoc Island is represented by about 100 species; only 33 of them are freshwater species. The major trends in the history of the island ichthyofauna were the elimination of true freshwater stenobiontic species and the progressive development of euryhaline and eurytropic species which replaced former species in seasonally variable biotopes of this relatively small tropic island. These eurytropic species are characterized by enough wide morphometric variability and do not demonstrate significant differences in their diagnostic characters comparing island and mainland populations.

During the estimated 10000 year time period of the fauna' isolation, only two of freshwater cypriniform species evolved into separate new taxa. These both species are characterized by the only common feature belonging to small short-lived species. This feature left them more possibilities for successive evolution. 
Summing up, based on the presently reported survey of the recent species of the Phu Quoc ichthyofauna, the evolutionary process in these fishes - characterized by a low founder effect and a weakly pronounced disruptive selection - resulted in a low number of the species evolved.

\section{ACKNOWLEDGEMENTS}

The authors thank biologists Dmitry A. Medvedev and Denis V. Prazdnikov (Severtsov Institute of Ecology and Evolution, RAS) and Vietnamese colleagues Nguyen Thi Nga and Trinh Thi Lan Chi (Vietnam-Russian Tropical Center, Ho Chi Minh) for their help in the field and the administration of Vietnam-Russian Tropical Center for the organization and financial support of field researches in the Phu Quoc Island.

\section{REFERENCES}

Alam M.A., Rahman L., Khan M.M.R., Rahman S.M.Z. 2006. Allozyme marker for the analysis of genetic variation of cross koi (ㅇ local x ô Thai) Anabas testudineus with their parents. Molecular Biology and Biotechnology Journal 4 (1-2): 71-75.

Allen G.R. 1991. Field guide to the freshwater fishes of New Guinea. Publication No. 9. Christensen Research Institute, Madang, Papua New Guinea.

Allen G.R. 1999. Ambassidae (= Chandidae). Pp. 2433-2455. In: Carpenter K.E., Niem V.H. (eds.) FAO species identification guide for fishery purposes. The living marine resources of the Western Central Pacific. Vol. 4. Bony fishes. Part 2 (Mugilidae to Carangidae). FAO, Rome.

Anderson W.D.jr, Allen G.R. 2001. Lutjanidae. Pp. 2840-2918. In: Carpenter K.E., Niem V.H. (eds.) FAO species identification guide for fishery purposes. The living marine resources of the Western Central Pacific. Vol. 5. Bony fishes part 3 (Menidae to Pomacentridae). FAO, Rome.

Bagarinao T. 1994. Systematics, distribution, genetics and life history of milkfish, Chanos chanos. Environmental Biology of Fishes 39 (1): 23-41.

DOI: $10.1007 / \mathrm{BF} 00004752$

Bignoli J.D. 2012. Barbucca diabolica. In: IUCN 2012. IUCN Red List of threatened species. Version 2012.1. http://www.iucnredlist.org.

Chakrabarty P., Oldfield R.G., Ng H.H. 2006. Nandus prolixus, a new species of leaf fish from northeastern Borneo (Teleostei: Perciformes: Nandidae). Zootaxa 2006 (1328): 51-61.

Collette B.B., Su J. 1986. The halfbeaks (Pisces, Beloniformes, Hemiramphidae) of the Far East. Proceedings of the Academy Natural Sciences of Philadelphia 138 (1): 250-301.

Doiuchi R., Nakabo T. 2005. The Sphyraena obtusata group (Perciformes: Sphyraenidae) with a description of a new species from southern Japan. Ichthyological Research 52 (2): 132-151.

DOI: $10.1007 / \mathrm{s} 10228-004-0263-1$

Emery K.O., Niino H. 1963. Sediments of the Gulf of Thailand and adjacent continental shelf. Geological Society of America Bulletin 74 (5): 541-554.

DOI: 10.1130/0016-7606(1963)74[541:SOTGOT]2.0.CO;2

Eschmeyer W.N. (ed.) 2012. Catalog of fishes. Electronic ver- sion (Accessed on 15 March 2012).

http://research.calacademy.org/research/ichthyology/cata $\log$ /fishcatmain.asp.

Esselstyn J.A., Timm R.M., Brown R.M. 2009. Do geological or climatic processes drive speciation in dynamic archipelagos? The tempo and mode of diversification in southeast Asia shrews. Evolution (USA) 63 (10): 2595-2610. DOI: $10.1111 / \mathrm{j} .1558-5646.2009 .00743 . \mathrm{x}$

Fang F., Kottelat M. 1999. Danio species from northern Laos, with descriptions of three new species (Teleostei: Cyprinidae). Ichthyological Exploration of Freshwaters 10 (3): 281-295.

Froese R., Pauly D. (eds.) 2012. FishBase. [version 02/2012] http://www.fishbase.org.

Fyhn M.B.W., Petersen H.I., Mathiesen A., Nielsen L.H., Pedersen S.A.S., Lindstrom S., Bojesen-Koefoed J.A., Abatzis I., Boldreel L.O. 2010. Vietnamese sedimentary basins: geological evolution and petroleum potential. Geological Survey of Denmark and Greenland Bulletin 20: 91-94.

Harrison I.J., Senou H. 1999. Mugilidae. Pp. 2069-2108. In: Carpenter K.E., Niem V.H. (eds.) FAO species identification guide for fishery purposes. The living marine resources of the Western Central Pacific. Vol. 4. Bony fishes part 2 (Mugilidae to Carangidae). FAO, Rome.

Heaney L.R. 1986. Biogeography of mammals in SE Asia: estimates of rates of colonization, extinction and speciation. Biological Journal of Linnaeus Society 28: 127-165.

Ivantsoff W., Crowley L.E.L.M. 1999. Atherinidae. Pp. 2113-2139. In: Carpenter K.E., Niem V.H. (eds.) FAO species identification guide for fishery purposes. The living marine resources of the Western Central Pacific. Vol. 4. Bony fishes part 2 (Mugilidae to Carangidae). FAO, Rome.

Kočetov A.M. 1991. Dekorativnoe rybovodstvo. [Ornamental fish.] Prosveščenie, Moskva, Russia. [In Russian.]

Kottelat M. 1985. Fresh-water fishes of Kampuchea. Hydrobiologia 121 (3): 249-279. DOI: 10.1007/BF00017547.

Kottelat M. 1989. Zoogeography of the fishes from Indochinese inland waters with an annotated check list. Bulletin Zoölogisch Museum. Universiteit van Amsterdam 12 (1): 1-56.

Kottelat M. 1990. Indochinese Nemacheilines. A revision of nemacheiline loaches (Pisces: Cypriniformes) of Thailand, Burma, Laos, Cambodia and southern Viet Nam. Verlag Dr. Friedrich Pfeil, München.

Kottelat M. 1998. Fishes of the Nam Theun and Xe Bangfai basins, Laos, with diagnoses of twenty-two new species (Teleostei: Cyprinidae, Balitoridae, Cobitidae, Coiidae and Odontobutidae). Ichthyological Exploration of Freshwaters 9 (1): 1-128.

Kottelat M. 2001. Fishes of Laos. Gunaratne Offset Ltd., Sri Lanka.

Kottelat M., Lim K.K.P. 1993. A review of the eel-loaches of the genus Pangio (Teleostei: Cobitidae) from the Malay Peninsula, with description of six new species. Raffles Bulletin of Zoology 41 (2): 203-249.

Kottelat M., Whitten A.J., Kartikasari S.N., Wirjoatmodjo S. 1993. Freshwater fishes of Western Indonesia and Sulawesi. Periplus Editions, Hong Kong.

Kottelat M., Witte K.E. 1999. Two new species of Microrasbora from Thailand and Myanmar, with two new generic names for small Southeast Asian cyprinid fishes 
(Teleostei: Cyprinidae). Journal of South Asian Natural History 4 (1): 49-56.

Koumans F.P. 1940. Results of a reexamination of type and specimens of gobioid fishes, with notes on the fish fauna of the surroundings of Batavia. Zoologische Mededeelingen 22: 121-210.

Koumans F.P. 1953. X. Gobioidea. In: Weber M., de Beaufort L.F. (eds.) The fishes of the Indo-Australian Archipelago. E.J. Brill, Leiden.

Kuznetsov A.N., [Kuznecov A.N.] Kuznetsova S.P. [Kuznecova S.P.] 2011. Lesnaya rastitel'nost' ostrova Fu Kuok. [Forest vegetation of Phu Quoc Island.] Pp. 7-52. In: Kalyakin M.V. [Kal'âkin M.V.] (ed.) Materialy zoologobotaničeskih issledovanij na ostrove $\mathrm{Fu}$ Kuok, Južnyj V'etnam. [Materials of zoological and botanical studies in Phu Quoc Island, South of Vietnam.] Tovariŝestvo naučnyh izdanij KMK [KMK Scientific Press.], Moscow-Hanoi. [In Russian with English summary.]

Larson H.K. 2001. A revision of the gobiid fish genus Mugilogobius (Teleostei: Gobioidei), and its systematic placement. Perth W.A., Records of the Western Australian Museum (Suppl. 62).

Larson H.K., Murdy E.O. 2001. Gobiidae. Pp. 3578-3603. In: Carpenter K.E., Niem V. (eds.) FAO species identification guide for fishery purposes. The living marine resources of the Western Central Pacific. Vol. 6. Bony fishes part 4 (Labridae to Latimeriidae), estuarine crocodiles. FAO, Rome.

Masuda H., Amaoka K., Araga C., Uyeno T., Yoshino T. (ed.). 1984. The fishes of the Japanese Archipelago. Vol. 1. Tokai University Press, Tokyo, Japan.

Matsuura K. 2001. Tetraodontidae. Pp. 3954-3957. In: Carpenter K.E., Niem V. (eds.) FAO species identification guide for fishery purposes. The living marine resources of the Western Central Pacific. Vol. 6. Bony fishes part 4 (Labridae to Latimeriidae), estuarine crocodiles. FAO, Rome.

McKay R.J. 1999. Sillaginidae. Pp. 2614-2629. In: Carpenter K.E., Niem V.H. (eds.) FAO species identification guide for fishery purposes. The living marine resources of the Western Central Pacific. Vol. 4. Bony fishes part 2 (Mugilidae to Carangidae). FAO, Rome.

McKay R.J. 2001. Haemulidae. Pp. 2961-2989. In: Carpenter K.E., Niem V.H. (eds.) FAO species identification guide for fishery purposes. The living marine resources of the Western Central Pacific. Vol. 5. Bony fishes part 3 (Menidae to Pomacentridae). FAO, Rome.

Mittermeier R.A., Gil P.R., Hoffmann M., Pilgrim J., Brooks T., Mittermeier C.G, Lamoreux J., Da Fonesca G.A.B. 2004. Hotspots revisited. CEMEX, Mexico City.

Munroe T.A., Wongratana T., Nizinski M.S. 1999. Clupeidae. Pp. 1775-1821. In: Carpenter K.E., Niem V.H. (eds.) FAO species identification guide for fishery purposes. The living marine resources of the Western Central Pacific. Vol. 3. Batoid fishes, chimaeras and bony fishes part 1 (Elopidae to Linophrynidae). FAO, Rome.

Nelson J.S. 2006. Fishes of the world. John Wiley and Sons, Hoboken, NJ, USA.

Nezdoly V.K., Serov D.V., Nguyễn D.T. 2005. Sơ bố bươc đâu vê thành phân loài cá suôi Trâîm (đào Phú Quốc, Tînh Kiên
Giang. [On fish species of the Cham River (Phu Quoc Island, Kien Giang Province)] Pp. 711-713. In: Proceedings of the National Workshop on research and technologies applied in aquaculture. 22-23 December 2004. Vungtau. Thành phố Ho Chi Minh. [In Vietnamese with English translation.]

Nezdoly V.K., [Nezdolij V.K.] Serov D.V., [Serov D.V.] Nguyen H.T. [Nguen Z.T.] 2011. O vidovom sostave ryb reki Čam, ostrov Fu Kuok, provinciâ Kien Giang, V'etnam. [On species of fishes of the Cham River, Phu Quoc Island, Kien Giang Province, Vietnam.] Pp. 65-67. In: Kalyakin M.V. [Kal'âkin M.V.] (ed.) Materialy zoologo-botaničeskih issledovanij na ostrove Fu Kuok, Južnyj V'etnam. [Materials of zoological and botanic studies in Phu Quoc Island, South of Vietnam.] Tovariŝestvo naučnyh izdanij KMK [KMK Scientific Press.], Moscow-Hanoi. [In Russian with English summary.]

Ng H.H., Hong D.K., Tu N.V. 2011. Clarias gracilentus, a new walking catfish (Teleostei: Clariidae) from Vietnam and Cambodia. Zootaxa 2011 (2823): 61-68.

Ng H.H., Kottelat M. 2008. The identity of Clarias batrachus (Linnaeus, 1758), with the designation of a neotype (Teleostei: Clariidae). Zoological Journal of the Linnean Society 153 (4): 725-732.

DOI: $10.1111 / j .1096-3642.2008 .00391 . x$

Ng H.H., Ng P.K.L. 1998. A revision of the south-east Asian catfish genus Silurichthys. Journal of Fish Biology 52 (2): 291-333. DOI: 10.1111/j.1095-8649.1998.tb00800.x

Ng H.H., Vidthayanon C., Ng P.K.L. 1996. Nandus oxyrhynchus, a new species of leaf fish (Teleostei: Nandidae) from the Mekong Basin. Raffles Bulletin of Zoology 44 (1): 11-19.

Ng H.H., Wirjoatmodjo S., Hadiaty R.K. 2004. Kryptopterus piperatus, a new species of silurid catfish (Teleostei: Siluridae) from northern Sumatra. Ichthyological Exploration of Freshwaters 15 (1): 91-95.

Otero-Villanueva M., Ut V.N. 2007. Sea cucumber fisheries around Phu Quoc Archipelago: A cross-border issue between South Vietnam and Cambodia. SPC Beche-de-mer Information Bulletin 2007 (25): 32-36.

Parenti L.R. 2008. A phylogenetic analysis and taxonomic revision of ricefishes, Oryzias and relatives (Beloniformes, Adrianichthyidae). Zoological Journal of the Linnean Society 154 (3): 494-610.

DOI: 10.1111/j.1096-3642.2008.00417.x

Pedersen S.A.S., Boldreel L.O., Madsen E.B., Filtenborg M.B., Nielsen L.H. 2010. Thin-skinned thrust-fault tectonics offshore south-west Vietnam. Geological Survey of Denmark and Greenland Bulletin 2010 (20): 99-102.

Rainboth W.J. 1996. Fishes of the Cambodian Mekong. FAO species identification field guide for fishery purposes. FAO, Rome.

Roberts T.R. 1989. The freshwater fishes of Western Borneo (Kalimantan Barat, Indonesia). Memoirs of the California Academy of Science 14: 1-210.

Roberts T.R. 1992. Systematic revision of the old world freshwater fish family Notopteridae. Ichthyological Exploration of Freshwaters 2 (4): 361-383.

Smith H.M. 1945. The fresh-water fishes of Siam, or Thailand. Bulletin of United States National Museum 188: 1-622. 
Smith M.M. 1986. Megalopidae. Pp. 155-156. In: Smith M.M., Heemstra P.C. (eds.) Smiths' sea fishes. Springer-Verlag, Berlin.

Steppan S.J., Zawadzki C., Heaney L.R. 2003. Molecular phylogeny of the endemic Philippine rodent Apomys (Muridae) and the dynamics of diversification in an oceanic archipelago. Biological Journal of the Linnean Society 80 (4): 699-715. DOI: 10.1111/j.1095-8312.2003.00274.x.

Taki Y. 1974. Fishes of the Lao Mekong Basin. United States Agency for International Development Mission to Laos Agriculture Division, Vientiane, Laos.

Vari R.P. 2001. Terapontidae. Pp. 3305-3316. In: Carpenter K.E., Niem V. (eds.) FAO species identification guide for fishery purposes. The living marine resources of the Western Central Pacific. Vol. 5. Bony fishes part 3 (Menidae to Pomacentridae). FAO, Rome.

Vidthayanon C. 2008. Field guide to fishes of the Mekong delta. Mekong River Commission, Vientiane, Laos.

Vidthayanon C., Karnasuta J., Nabhitabhata J. 1997. Diversity of freshwater fishes in Thailand. Office of Environmental Policy and Planning, Bangkok, Thailand.

Westneat M.W. 2001. Labridae. Pp. 3381-3467. In: Carpenter K.E., Niem V. (eds.) FAO species identification guide for fishery purposes. The living marine resources of the Western Central Pacific. Vol. 6. Bony fishes part 4 (Labridae to Latimeriidae), estuarine crocodiles. FAO, Rome.

Woodland D. 2001a. Gerreidae. Pp. 2946-2960. In: Carpenter K.E., Niem V. (eds.) FAO species identification guide for fishery purposes. The living marine resources of the Western Central Pacific. Vol. 5. Bony fishes part 3 (Menidae to Pomacentridae). FAO, Rome.

Woodland D. 2001b. Siganidae. Pp. 3627-3650. In: Carpenter K.E., Niem V. (eds.) FAO species identification guide for fishery purposes. The living marine resources of the Western Central Pacific. Vol. 6. Bony fishes part 4 (Labridae to Latimeriidae), estuarine crocodiles. FAO, Rome.

Yalçin Ş., Solak K., Akyurt İ. 2001. Certain reproductive characteristics of the catfish (Clarias gariepinus Burchell, 1822) living in the River Asi, Turkey. Turkish Journal of Zoology 25 (4): 453-460.

Received: 26 March 2012

Accepted: 20 August 2012

Published electronically: 30 September 2012 